\title{
JUAN DE HERRERA Y LAS REGLAS DE LA COFRADÍA DE LA VERA-CRUZ. UNA CONTRIBUCIÓN AL ESTUDIO DE LA MINIATURA SEVILLANA DEL SIGLO XVII
}

\author{
POR TERESA LAgUNA PAÚl
}

Juan de Herrera, hermano de Francisco de Herrera el viejo, iluminó la Regla de la Cofradía de la Vera-Cruz (1627-1631), única conservada de los dos libros de reglas que le encargaó esta hermandad sevillana. Esta investigación estudia el contrato, la confección, las miniaturas e iniciales del manuscrito y da a conocer la personalidad artística de este pintor sevillano, iluminador y diseñador de portadas para libros impresos.

Juan de Herrera - the brother of Francisco de Herrera "The Old"-, illustrated "The Rules of the Vera-Cruz Brotherhood" (1627-1631), the only one preserved of the two books of rules entrusted to him by this sevillian Brotherhood. The study deals with the contract, preparation, miniatures and capital personality of this sevillian painter, illustrator and designer of covers for printed books.

Los libros de reglas son uno de los documentos más importantes de las hermandades religiosas porque constituyen la principal fuente jurídico-normativa de su gobiemo, administración e historia. Sin embargo, son un patrimonio apenas analizado por la $\mathrm{H}^{\mathrm{a}}$ del Arte, aunque en estos manuscritos se realizaron iluminaciones desde el siglo XV al XVII. La Regla de la Cofradía de la Vera Cruz representa un caso excepcional entre las conservadas en Sevilla. Las vicisitudes por las que pasó esta institución durante el siglo XIX y su casi total extinción en 1925 hizo que, en época de la Segunda República y por causas no bien conocidas, el arzobispado las depositase en la Biblioteca Provincial y Universitaria de Sevilla, donde se encuentran con la signatura ms. 331/224. 
El manuscrito es conocido en la ciudad y ha sido expuesto, al menos, en dos ocasiones, en las que su iluminación se atribuyó a Melchor Riquer, nombre que consta con interrogación en la ficha catalográfica de este depósito ' No obstante López Martínez publicó con anterioridad unos extractos notariales del encargo en 1627 y pago final en 1636 realizado a Juan de Herrera por la iluminación de dos reglas para la Hermandad de la Vera Cruz de Sevilla ${ }^{2}$. Martínez Ripoll desveló que éste era hermano de Francisco de Herrera, el viejo, pintor que había realizado para la misma institución una conocida serie pictórica entre $1614-1616^{3}$. Esta documentación confirmaba de forma evidente la autoría de las dos reglas, pero desvelar cuando se realizó verdaderamente el libro y la personalidad artística del iluminador Juan de Herrera sólo puede conocerse analizando el manuscrito.

\section{LA COFRADÍA DE LA VERA CRUZ DE SEVILLA Y SUS DOS REGLAS}

Los orígenes de la Hermandad de la Vera Cruz de Sevilla se inscriben en el movimiento de confraternidades laicas bajo-medievales que tienen como finalidad el culto al Símbolo de la Redención y realizar actos de penitencia pública. La cofradía se constituyó en 1448 y veinte años más tarde está documentada la primera salida procesional con hermanos de sangre [disciplinantes] y luz acompañados por una representación de la comunidad franciscana del convento Casa Grande de esta ciudad, donde tuvo desde el comienzo su residencia canónica ${ }^{4}$.

Inicialmente ocupó una capilla situada junto a la portería del convento, hasta que en 1478 adquirió otra muy espaciosa ubicada en el claustro principal, aledaña a la sacristía de la iglesia conventual. Este recinto, ocupado hasta la demolición del cenobio en 1863, constituía, según la descripción del padre Lugones en 1615, un

1. Tesoros ocultos de las hermandades de Sevilla, Sevilla Monte de Piedad marzo-abril $1985, \mathrm{~N}^{\circ}$ Cat. LD. 5. Vera Cruz, Sevilla Caja San Fernando 5-22 marzo 1992, p. 9.

Melchor Riquer sólo es conocido por una vaga referencia de Ceán Bermúdez. Detrás de este nombre debe esconderse la personalidad de Melchor Riquelme, escritor de libros y autor de letras quebradas, quien se hizo cargo del escriptorio catedralicio en 1583. A. CEÁN BERMÚDEZ: Diccionario de las Bellas Artes en España, Madrid 1800, T. IV p. 200. J. GESTOSO: Ensayo de un diccionario de artífices que florecieron en la ciudad de Sevilla desde el siglo XIII al XVIII, Sevilla 1908, T. III p. 134. C. ALVAREZ MÁRQUEZ: El mundo del libro en la iglesia catedral de Sevilla en el siglo XVI, Sevilla 1992, pp. 190-193, 318-328.

2. C. LÓPEZ MARTÍNEZ: Arquitectos, escultores y pintores vecinos de Sevilla, Sevilla 1928, $\mathrm{p}$. 62; Desde Martínez Montañés hasta Pedro Roldán, Sevilla 1932, p. 186.

3. A. MARTÍNEZ RIPOLL: Francisco de Herrera el viejo, Sevilla 1978, pp. 15-16, 39. $\mathrm{M}^{2} \mathrm{~J}$. del CASTILLO UTRILLA: El convento de San Francisco, Casa Grande de Sevilla, Sevilla 1988, p. 98

4. A.SÁNCHEZ GORDILLO: Religiosas estaciones que frecuenta la religiosidad sevillana, ed. J. Bernales Sevilla 1983, p. 151. J. BERMEJO y CARBALLO: Glorias religiosas sevillanas o noticias histórico-descriptivas de todas las cofradias de penitencia, sangre y luz fundadas en esta ciudad, Sevilla 1882 (reed. 1977) p. 349. 
espacio espléndidamente decorado ${ }^{5}$. Numerosas rentas y posesiones permitieron a la cofradía realizar importantes obras y encargos artísticos, entre otros, la serie de doce lienzos con la historia de la Vera Cruz realizada por Francisco de Herrera, el viejo, (1614-1616) y la Inmaculada con fray Juan de Quirós de Bartolomé Esteban Murillo (1652) ${ }^{6}$. La decoración de la capilla se completaba con un zócalo de azulejos y sobre éste franjas de frescos con ramas y flores separaban los lienzos de Herrera, quizás semejantes a las guirnaldas de frutos que pueden verse en la mencionada obra de Murillo ${ }^{7}$.

Las primeras reglas de la cofradía fueron ordenadas en 1448, pero no se presentaron a la autoridad eclesiástica y no se aprobaron hasta 1501. Más tarde se redactaron otras, sancionadas el 18 de mayo de 1538, que tenían cincuenta y dos capítulos y una cláusula que permitía posteriores ampliaciones. Los cabildos celebrados el 5 de mayo y 9 de junio de 1631 añadieron un nuevo capítulo que establecía cambios en el número de diputados perpetuos, aceptado por el provisor de Sevilla Luis de Venegas y Figueroa el 9 de noviembre de $1634^{8}$.

Entre las acciones benéficas que realizaba esta cofradía estaba la dotación de doncellas pobres, actividad muy común en la Sevilla del siglo XVI. Para el buen funcionamiento de esta obra pía se aprobó otra regla, diferente de la anterior, el 7 de junio de 1565 que reguló su administración y funcionamiento. Su finalidad primordial era la dotación anual el 11 de junio, fiesta de San Bernabé, de doncellas para el matrimonio o el ingreso en la vida religiosa; en algunas ocasiones también se redimieron cautivos durante los siglos XVI y XVII. La existencia de esta regla queda confirmada por la descripción recogida en el cabildo celebrado el 16 de junio de 1613: "Item, un libro pequeño escrito en pergamino, cubierto de tercio pelo verde, en que estan las reglas de la dotación de doncellas" 9.

5. P. DE LUGONES, Carta al Ilmo. y Rmo. Señor Cardenal Çapata, del padre Damian de Lugones, Guardian del Conuento de San Francisco de Seuilla, en la qual responde a su illustrissima, dandole cuenta de la solemnissima fiesta, y Octauario, que el dicho Conuento hizo a la Inmaculada Concepcion de la Virgen nuestra Señora, en ocho de Diziembre del año de mil y seyscientos y quinze, con todo el adereço de la Yglesia, y Capillas, Altares, Claustro, Sermones, Processiones, Fuegos, y todo lo demas que en la fiesta vuo, Sevilla, Gabriel Ramos Vejarano, 1615. p. 25r-v.

6. A. MARTÍNEZ RIPOLL: Francisco de Herrera, cit. pp. 140, 196-200. E. VALDIVIESO y J.M. SERRERA, Pintura sevillana del primer tercio del siglo XVII, Madrid 1985, p. 43. $\mathrm{M}^{\mathrm{p}} \mathrm{J}$. del CASTILLO UTRILLA, El convento... cit. pp. 94-98.

7. P. de LUGONES, Carta... cit. p. 25v: "Sobre los azulejos hasta empanejar con el techo estan asentados quadros de pintura en sus bastidores, y guamiciones doradas, estos cuadros [...]. Entre quadro y quadro el espacio que queda vazio de pared, que es de a vara, y mas pintado todo de vnas hermosissimas ramas y flores."

8. B.U.S. ms 331/224 fols. 4v-5, 32, 43-47v. Sobre el contenido textual véase J. MESSEGUER FERNÁNDEZ, O.F.M.: "Las cofradías de la Vera Cruz. Documentos y notas para su historia" en Archivo Ibero-Americano n' 109-110 (1968) 119-213. J. SÁNCHEZ HERRERO: "Hermandad de la Santa Vera Cruz. Sevilla, 1538, 1631" en C.E.I.R.A. 4 (1995) pp. 1 y siguientes.

9. J. SÁNCHEZ HERRERO: "La dotación de doncellas en la Cofradía y Hermandad de la Santa Vera Cruz de Sevilla 1595-1832" en Las cofradias de la Santa Vera Cruz. Actas del primer congreso internacional, Sevilla 19-22 mayo 1992, Sevilla 1995, pp. 72 y ss. 


\section{LA EJECUCIÓN DEL MANUSCRITO. LOS DATOS DOCUMENTALES.}

Hacia 1627 la hermandad debió acordar realizar una copia lujosa de estas dos reglas, para lo cual establecerían las pertinentes consultas y entrevistas entre los escritores de libros e iluminadores que trabajaban en Sevilla. El motivo y la persona o personas que acordaron sus características iconográficas y decorativas aún es desconocido, pero fue anterior a la copia del texto, porque la realización del libro manuscrito siempre implica una preparación previa a su ejecución que no puede dejarse al azar. Los libros nuevos fueron copiados por Andrés Camacho y miniados por Juan de Herrera, pero sólo se conserva la regla de la cofradía, objeto de este estudio. La importancia y coste del trabajo generó una interesante documentación notarial, cuyo complemento se encuentra en el archivo de la hermandad.

Andrés Camacho era escritor de libros de la catedral de Sevilla donde está documentado desde la segunda década del siglo XVII hasta, al menos, 1655. Su trabajo para el cabildo consistía fundamentalmente en la confección de los cuadernos o "quadrantes" donde se anotaban las horas del coro a los prebendados, y la copia y reparación de libros corales. Entre 1636 y 1644 escribió el Libro Blanco de dotaciones. Esta labor la simultaneaba con otros encargos como, por ejemplo, los libros que realizó para la iglesia de Villamartín ${ }^{10}$. Entre 1630-1631 trabajó en unos libros corales nuevos, que deben corresponder a los textos compuestos por Sebastián Vicente Villegas, maestro de ceremonias del cabildo, como el Segundo Cuerpo de Misas Votivas que tiene una inicial de tinta firmada con las letras A.C. y la fecha de $1630^{11}$. La decoración de esta inicial es muy característica y aparece también en otros libros corales donde pudo intervenir dejando constancia del año ${ }^{12}$.

Con anterioridad a estas últimas obras ya había copiado el texto de las dos reglas de la Vera Cruz, que le fue abonado el 22 de septiembre de $1627^{13}$. Los cuadernos entregados tenían folios en blanco para posteriores ampliaciones y también dejó . preparados los espacios destinados a recibir la iluminación, que fue contratada un mes más tarde con Juan de Herrera.

10. J. GESTOSO y PÉREZ, Ensayo..., Cit. T. I p. 208-209, T. III p. 124. ARCHIVO CATEDRAL DE SEVILLA [A.C.S.], Leg. sig. prov. 0823, fols. 20, 27v, 30, 37, 85v, 111, 220v, 214 y 227v; Leg. sig. prov. 2211 fol. 1.

11. A.C.S. Leg. sig. prov. 0823, fols. 125, 138 y 279v. CATEDRAL DE SEVILLA, Librería Coral: L. 102, fol. 50v; fue confeccionado en 1629-1630 según las fechas de los fols. IIIv, VIIv, Lv, y XCI.

12. CATEDRAL DE SEVILLA, Librería coral: L. 98, fol. 71 año 1624; L. 25, fol. 25 y 74 año 1630; L. 101, fol. 107v año 1632 .

13. ARCHIVO HDAD. VERA CRUZ DE SEVILLA [A.V.C.S.] Libro de quentas de mayordomos desde el año 1612 hasta 1632, fol. 133v: "Pagos describir las Reglas. Ytem 771 reales que por librança de 22 de septiembre de 627 pago Andrés Camacho escriptor de libros por las bitelas pergamino y ocupazión que tuvo en escrevir las dos reglas tocantes a la cofradía y patronazgo de doncellas que dio recivo". 
Juan de Herrera nació en la última década del siglo XVII y era segundo hijo del grabador e iluminador Juan de Herrera Aguilar ${ }^{14}$. Al igual que su hermano Francisco de Herrera, el viejo, debió realizar el aprendizaje en el taller paterno y una vez obtenida la maestría, es posible que, como su progenitor, se dedicara a la ilustración libraria, pues se denomina maestro iluminador $y$, al menos, realizó el diseño de una portada sacada a buril por Alardo de Popma en 1632 (Lám. 11). Las relaciones de su hermano Francisco con esta cofradía desde 1614 debieron tenerse muy en cuenta a la hora del encargo, realizado cuando tendría aproximadamente treinta y cinco años.

Según el contrato, Juan de Herrera se comprometió ante Baltasar de Valdés, escribano público de Sevilla, que era hermano de esta cofradía, a realizar la iluminación de las dos reglas en un tiempo no superior a ocho meses y recibió del mayordomo Lorenzo del Río Estrada 500 reales a cuenta ${ }^{15}$. El documento alude a unas muestras presentadas, menciona reiteradamente el plazo de ejecución y la posibilidad de rescindirlo si ésto no se cumplía, posiblemente porque la hermandad no deseaba que hubiera una demora excesiva como ocurrió con los lienzos de Francisco de Herrera. Sin embargo, pese a estas cláusulas, debieron existir algunas diferencias entre el iluminador y la cofradía.

La contabilidad de la hermandad no refleja en 1627 este adelanto y sí los emolumentos abonados al escribano público ${ }^{16}$. La primera anotación a Juan de Herrera es año y medio posterior a la carta de concierto y obligación. Sin embargo ¿por qué no se rescindió el contrato?. Al parecer Herrera no cobró esta cantidad en el momento del protocolo -noviembre de 1927- sino en $1630{ }^{17}$. Este hecho no es un reflejo de la picaresca del siglo XVII, sino de todas las épocas porque el notario da fe de algo que dicen dos partes puestas de común acuerdo, pero no tiene obligación de comprobarlo. El asunto originaría sus lógicos problemas entre el iluminador y la institución durante un tiempo, pero no invalidaba el encargo.

Entre los meses de junio y septiembre de 1629 Juan de Herrera recibió nuevos adelantos en tres pagos fraccionados que ascienden a 20.400 maravedíes ${ }^{18}$. En 1630 la iluminación de la Regla de la Cofradía estaría muy avanzada porque la hermandad

14. A. MARTÍNEZ RIPOLL, Francisco de Herrera, el viejo, cit. p. 15-16, 39.

15. ARCHIVO HISTÓRICO PROVINCIAL DE SEVILLA [A.H.P.S]. Legajo 1224, fols. 713-714v. C. LÓPEZ MARTÍNEZ, Arquitectos... Cit. p. 62. Apéndice Doc. $\mathrm{n}^{\circ} 1$

16. A.V.C.S. Libro de quentas..., fol. 133v: "Derechos descripturas 1627. Ytem da en data $3.876 \mathrm{mrs}$ pagados a Baltasar de Valdes escribano público de Sevilla por los derechos de escripturas y recaudos que sean echo en su ofiçio tocantes a la cofradía de la Vera Cruz de que dio rrezivo".

17. A.V.C.S. Libro de quentas..., fol. 208 ."Luminacion de la regla. Ytem se le hazen buenos al dicho Juan Mendez 17.000 maravedíes por 500 reales que dio a Juan de Herrera yluminador el qual los rezivió en el ano pasado de 1627 en cuya quenta se le avían de abonar y no se hizo como pareze por la escriptura de concierto que con el se hizo en la qual confiesa aver rezevido los dichos 500 reales y por no averse fecho buenos en las quentas de 1627,1628-1629 se le abonan en esta de 1630".

18. A.V.C.S. Libro de quentas..., fol. 189: "Ytem se le rreziven en quenta al dicho Juan Mendez 20.400 mrs que a pagado a Juan de Herrera por escreuir yluminar la regla dela santa cofradia y es a quenta de lo que a de auer los $10.200 \mathrm{mrs}$ por librança de 27 de junio de 1629 y los $6.800 \mathrm{mrs}$ por librança de 10 de mayo de 1630 y los 3.400 mrs rrestantes por librança del contador Lorenzo del RRio Estrada de 30 de septiembre de 1630.20 .400 maravedíes". 
adquirió el tafetán y terciopelo verde necesario para la encuademación y, según se lee en el frontispicio del manuscrito, ésta fue terminada el 17 de marzo de $1631{ }^{19}$ (Lám. 1).

Juan de Herrera debió entregar inmediatamente el volumen para que la cofradía pudiera llevar la regla en la estación de penitencia del jueves santo de este año. El acto de entrega pudo ser, incluso, solemne o público el 10 de abril de 1631, día que coincidía con el sexto viernes de cuaresma, fiesta de la Adoración de la Santa Cruz y día en el cual el iluminador percibió un nuevo adelanto ${ }^{20}$. En esta fecha el iluminador había realizado la mitad del contrato y tenía cobrada la misma proporción de dinero acordado. Debió tomarse con calma, sin prisas, la iluminación de la Regla de dotación de doncellas y lógicamente realizó otros encargos comprometidos, como el diseño de la portada del Novus index librorvm prohibitorvm et expvrgatorvum; editus auctoritate \& lussu eminentissimi ad Reuerendendissimi D. Antonii Zapata, grabada por Alardo de Popma e impreso en Sevilla por Francisco de Lyra en $1632^{21}$ (Lám. 9). En agosto de 1636 recibió nuevamente dinero de la hermandad, pero es imposible determinar cuanto tiempo tardó y cuando trabajó en la Regla de Doncellas. Sólo se sabe que tres meses más tarde, el 19 de noviembre, los dos trabajos comprometidos estaban concluidos satisfactoriamente. Ese día Juan Méndez de Trapa, receptor y cobrador del mayordomo Jerónimo de Barreda, dio a Herrera los 700 reales restantes y el iluminador entregó la carta de pago ante el notario Juan de Loaysa, que quedó reflejada inmediatamente en la documentación administrativa de la hermandad ${ }^{22}$. No obstante, no puede olvidarse que la firma del finiquito no equivale a una terminación de la obra, sino de su pago.

19. A.V.C.S. Libro de quentas..., fol. 206: "Gastos de menudo de 1630.49 reales por 7 baras de tafetán verde para la regla nueva a siete reales la vara. Ytem 30 reales de media bara de terciopelo berde para aforrar las tablas de la rregla".

B.U.S. 331/224 fol. 1: "Acabose ano, 1631, a 17 de março, por comicion de los señores diputados de la Santisima Vera Cruz".

20. A.V.C.S. Libro de quentas..., fol. 240 : "Juan de Herrera 500 reales por la librança de diez de abril de 1631 para quenta de yluminacion de las reglas con que a rrecevido 10600 reales".

21. T. LAGUNA PAÚl, "Vera Cruz" en Patrimonio de la Universidad de Sevilla, Sevilla 1995, cat. $n^{\circ} 65$.

22. A.H.P.S. Leg. 14.544, fol. 1.158. C. LÓPEZ MARTÍNEZ: Desde Martínez...., opus cit. p. 186. Apen. Doc. $n^{\circ} 2$.

A.V.C.S. Libro de quentas ...., fol. 293. "N 27.- Resto que se pago a Juan de Herrera por la yluminaçion de la rregla. Años 1636-1637

- Mas se le rreziven en quenta a los Juan Mendez 55.800 mrs que pago a Juan de Herrera yluminador de rresto de la yluminacion de la regla de que se dieron libranzas que las que son la cantidad de cada una son los siguientes

- Por libranza de 13 de agosto de 163610 reales que valen treinta y quatro mill maravedises librados a Juan de Herrera de que dio recibo en 19 de agosto de 1636. 34.000

- Por libranza de 19 de noviembre de 1636700 reales que balen $23.800 \mathrm{mrs}$ de rresto de los 3.300 reales que llevo por la yluminacion de la rregla de que dio carta de pago en 19 de noviembre de 1636 ante Juan Rodriguez de Loayssa escrivano publico de Sevilla. 23.800

- que las dichas partidas montan los dichos 57.800 cinquenta y siete mill y ochozientos mrs como dellos asiento". 


\section{CARACTERÍSTICAS CODICOLÓGICAS}

La estructura diplomática de las reglas de hermandades es bastante constante. Dos o cuatro páginas iluminadas recogen las imágenes o temas iconográficos vinculados al carácter y titularidad de la asociación y precede a la invocación, que forma unidad con el preámbulo. Seguidamente viene la intitulación donde consta su nominación completa e indicación del lugar donde se encuentra, el dispositivo de promesa y la relación de los capítulos. Presentan también cláusulas de sanción y corroboración por la autoridad eclesiástica que en los documentos originales están rubricadas, mientras las copias carecen de esta validación. La tabla de capítulos puede preceder a la intitulación o situarse al final ${ }^{23}$.

El ms. 331/224 de la Biblioteca Universitaria de Sevilla es una copia de la Regla de la cofradía de la Santísima Vera Cruz de Sevilla, que debe reproducir las vigentes en 1631, ampliadas en 1634. La carencia de rúbricas, los datos aportados por el texto y el estudio codicológico así lo confirman.

Se compone de 57 folios de pergamino bien curado de $282 \times 192 \mathrm{~mm}$.. Los dos primeros folios y el último son de salva; en los demás una mano moderna realizó la paginación a lápiz, numerando correlativamente en arábigos del 1 al 54 . El volumen comprende siete cuadernillos regulares de cuatro folios cada uno, cuaterniones, que comienzan por la cara del pelo y mantienen la llamada ley de Gregory.

La construcción de la justificación fue realizada partiendo de pinchazos en la cara hipodérmica, verticales y horizontales, que sirvieron de guía al pautado a lápiz y pueden verse en los márgenes del folio. Las líneas rectrices mayores son dobles y se prolongan hasta el límite de la página; la unidad de pautado es de $9 \mathrm{~mm}$. y los renglones se retintaron en rojo. Todos los folios están decorados con un marco miniado con decoración aurífera de pluma sobre fondo carmín, que resalta decorativamente la caja de escritura de 222 x $128 \mathrm{~mm}$.. Las orlas de las páginas llenas están recogidas en el contrato, posiblemente por su mayor laboriosidad y coste ${ }^{24}$.

Cada página tiene vientitres renglones escritos en gótica textual redondeada, pero en el texto se observan dos etapas de copia. Las fórmulas preliminares, los textos escritos desde el folio 3 al $45 \mathrm{v}$, y las tablas (fol. 50-54) fueron las que realizó Juan Camacho con una escritura cuidada; también dejó páginas en blanco para posteriores ampliaciones ${ }^{25}$. El capítulo LIII fue incluido pocos años más tarde, no se anotó en el índice y recoge el mencionado acuerdo de 1631 sancionado en 1634 (Lám. 10). Esta ampliación, como se ha indicado anteriormente, estaba prevista no sólo por los estatutos sino también por el primer copista. Posiblemente fuera el mismo Juan Camacho quien lo insertó en los folios 46r-47v, pero los rasgos de la

23. A.J. LÓPEZ GUTIÉRREZ y J. RODRIGUEZ MATEOS: Los archivos de las hermandades religiosas. Manual de organización de sus fondos, Sevilla 1993, pp. 73-80.

24. A.H.P.S. Leg. 1224 fol. 713r-v: "las ordas de todas las planas an de ser labradas en oro, açul y carmín". C. LOPEZ MARTIMEZ, Arquitectos... Cit., p. 62. Apéndice Documental n.1

25. B.U.S. ms. 331/224 fols. 3r-45r, 50r-54r. Actualmente están en blanco y con el marco miniado los fols. $48-49 v$. Vid. nota ${ }^{\circ} 13$. 
letra evidencian algunos trazos diferentes, debidos al cambió de pluma, y las palabras tienen una separación menor. Esta incorporación textual no motivó una reencuadernación.

El volumen está encuadernado con tapas de madera cubiertas con terciopelo verde oscuro, actualmente muy raído, adquirido en 1630. Esta encuadernación original ha perdido los dos broches de cierre y tiene restos de los clavos que fijaban, en la tapa anterior y posterior, una tarja metálica con el escudo de la hermandad. Entre folio y folio, desde el primero hasta el último, quedan cincuenta y dos cortinillas de tafetán verde protegiendo la iluminación desde su origen; se ignora el nombre del encuadernador ${ }^{26}$.

\section{LA ILUMINACIÓN}

El volumen presenta una extraordinaria decoración si lo comparamos con otras reglas conservadas de las hermandades sevillanas ${ }^{27}$. El elevado número de sus ilustraciones no es el habitual en este tipo documental, ni tampoco el empleo de iniciales con figuras para los capítulos.

La técnica es al temple siguiendo el método que Francisco Pacheco denomina segundo modo de iluminar o antiguo donde las carnaciones son al natural, cubriendo la vitela ${ }^{28}$. El oro molido fue aplicado a pincel y tiene una calidad mate, quizá debida a la mezcla realizada ${ }^{29}$.

Estilísticamente tiene rasgos tardomanieristas, en sintonía con la pintura contemporánea sevillana y los libros de coro catedralicios realizados hacia 1630. La gama cromática es variada, con colores intensos y contrastantes, muy manierista. Las figuras presentan un predominio de la línea y los volúmenes están conseguidos mediante sombreados violentos, aunque, en ocasiones, también existe una gradación tonal. En las carnaciones se empleó el albayalde con matices rosáceos en mejillas y toques grises para conseguir la expresividad individualizadora de los rostros.

La iluminación destaca el contenido textual, pero el programa iconográfico quizás fue pensado por los propios franciscanos del convento Casa Grande de Sevilla, que asesorarían al mayordomo y cofrades de la Vera Cruz. Éstos se lo exigirían al artista

26. Vid. nota $\mathrm{n}^{\circ}$ 19. En la encuadernación se empleó todo el tafetán -siete varas-, y sobró terciopelo para las tapas de la Regla de dotación de doncellas.

27. Tres exposiciones han mostrado reglas cuya cronología abarcaba desde el s. XVI hasta principios del XIX. Tesoros ocultos de las hermandades de Sevilla, Sevilla Monte de Piedad marzo-abril 1985, N$^{\circ}$ Cat. L.D. 1- L.D. 13; Tesoros ocultos de las hermandades de Sevilla II, Sevilla Monte de Piedad febreromarzo 1985, $\mathrm{N}^{\circ}$ Cat. L.D. 3-L.D. 10; Arte en las Hermandades de Sevilla, Sevilla Monte de Piedad febrero-marzo 1986, $\mathrm{N}^{\circ}$ Cat. L.D. 2, L.D. 4-5, L.D. 7-9.

28. Fco. PACHECO: Arte de la pintura, Sevilla 1638, fols. 374 y 376. Ed. del manuscrito por F.J. SÁNCHEZ CANTÓN, Madrid 1956, T. II pp. 34, 37.

29. Fco. PACHECO: Arte..., cit. fol. 379, p. 41. Al indicar el tercer modo de moler el oro Pacheco dice: "..., si se gasta sobre la vitela sola, se dará debaxo con la agua de goma con que se ilumina y un poquito de azafrán". 
que haría unas muestras, previas al encargo como control de calidad. Según el contrato la Regla de la Cofradía debía tener cuatro planas o páginas llenas con orlas, que preceden al texto, una invocación realizada con el mismo carácter, e iniciales con figuras de santos en los capítulos. La ejecución refleja un planteamiento jerarquizado tanto en los contenidos como en los grupos.

\subsection{Iuminaciones a página llena}

Juan de Herrera iluminó en el frontispicio una doble tarja manierista de vivo colorido sobre un fondo rojizo decorado con trazos y punteado de oro, que se atiene perfectamente al contrato: primeramente una tarja en el principio de la dicha regla ${ }^{30}$. Esta cartela, aunque inspirada en estampas de Agostino Carracci, copia directamente el motivo central de la estampa realizada por Francisco de Herrera en 1627 titulada La exaltación de la orden Trinitaria, que fue regalada por estos religiosos al CondeDuque de Olivares ${ }^{31}$. El iluminador no se contentó con recoger el modelo geométrico sino que traspasó también con un rico colorido las tres cabezas de angelotes situadas en la parte superior. La tarja superior es mas sencilla y cobija el escudo de la cofradía, una cruz de gajos verdes y cinco llagas. La composición se completa con efectos manieristas, como son el empleo de colgaduras de las que penden racimos de naranjas, limones, granadas y uvas, entre otros frutos. Estos motivos ornamentales también los empleó su hermano Francisco en el grabado del Commentarii in Summan Theologiae S. Thomas de J. Granado (Sevilla, Francisco de Lyra, 1623), y deben estar inspirados en estampas de Agostino Carracci y Tempesta, entre otros. En la parte inferior una moldura enmarca la fecha de terminación del manuscrito (Lám. 1 y 10).

La influencia de Francisco de Herrera es muy directa en otras páginas llenas, como el santo Christo con dos penitentes a el pie y su çenefa con figuras ${ }^{32}$. En el folio $1 \mathrm{v}$ hay un altar presidido por un crucificado ante el que oran dos disciplinantes. El Señor copia directamente el crucificado de la mencionada estampa de la orden Trinitaria, Juan de Herrera se limitó a modelar con color la figura y sólo sustituyó la cruz plana por una arbórea. Los dos cofrades vestidos con "camisas" y "capirotes romos" blancos son disciplinantes ataviados como indica la regla; los hermanos de luz iban de negro y a ambos lados en la procesión ${ }^{33}$. La "çenefa" que enmarca el

30. A.H.P.S. Legajo 1224, fol. 713. C. LOPEZ MARTINEZ, Arquitectos..., cit. p. 62. Apén. Doc. 1

31. Sobre este grabado Vid. A. MARTÍNEZ RIPOLL "Francisco de Herrera el viejo, grabador", en Actas del XXIII congreso Internacional de Historia del Arte (Granada 1973), Granada 1978, T. III pp. 145-153; Francisco de Herrera, Cit. p. 92-93.

32. A.H.P.S. legajo 1224, fol. 713. C. LOPEZ MARTINEZ, Arquitectos..., cit. p. 62. Apén. Doc. 1

33. B.U.S. ms. $331 / 224$ fol. $12 \mathrm{r}-\mathrm{v}$ cap. X: " sean obligados a traer cada uno su aparejo de camisa y disciplina e las camisas sean de angeo curado largas hasta el suelo con capirotes romos que cubran el rostro, e que la disciplina sea de manojo con sus rodezuelas o con lo que algunos hermanos acostumbran a hazer su disciplina e todos los hermanos lleven ceñidos cordones de Sant Francisco, e sus escudos en los pechos con la insignia de la Santa Vera + e sangre de Jesu Christo, los quales escudos an de ser de guadamecí, e no de plata, ni de oja de Milán, ni de otro metal, ni de papelón yluminado so pena que el 
folio está presidida en la parte superior por Dios Padre y el Espíritu Santo y en la inferior el escudo de la hermandad, ambos dentro de tarjas portadas por angelitos. Dentro de medallones e insertos en cartelas manieristas aparecen los evangelistas, en los ángulos, y San Roque y San Sebastián, en los flancos verticales. Estos santos sanadores es frecuente encontrarlos vinculados a los hospitales que tenían las cofradías de la Vera $\mathrm{Cruz}^{34}$. La hermandad sevillana no tuvo ninguna institución de este carácter pero las fiestas de ambos santos -16 de agosto y 20 de enero- están recogidas entre las anuales que se celebraban por los cofrades vivos y difuntos ${ }^{35}$ (Lám 2).

$\mathrm{El}$ folio $2 \mathrm{v}$ está descrito en el contrato como una tarja con la cruz y quatro donsellas con escapularios berdes y belas ${ }^{36}$. La miniatura está inspirada directamente en el cuadro de Nuestra Señora que realizó Herrera el viejo para la serie de la Vera Cruz sevillana (1614-1616), localizado por Martínez Ripoll en el palacio arzobis$\mathrm{pal}^{37}$. Aquí la Inmaculada fue sustituida por el emblema de la institución, inserto en otra tarja igual a las laterales de la mencionada estampa de la Orden Trinitaria y flanqueada por unas figuras aladas que también recuerdan otras de diseño fraterno en las yeserías del convento de San Buenaventura de Sevilla. Las doncellas no son cuatro, sino un grupo numeroso dispuesto con isocefalia y arrodillado bajo el escudo protector. Las velas o cirios son todos verdes al igual que en el altar del crucificado, tal como prescribe la regla y describe fray Francisco de Aldana en la procesión de 1621, aunque el abad Gordillo dice que los empleaban amarillos hacia $1630-1632^{38}$ (Lám. 4).

La representación de la ymagen de nuestra sennora de la pura y linpia Consepsion del fol. 2. está vinculada iconográficamente al contexto franciscano en el que se circunscribía la hermandad, pues el convento de San Francisco de Sevilla fue el escenario de una importante fiesta celebrada a la Inmaculada en diciciembre de $1615^{39}$. Tampoco puede olvidarse que Sevilla fue la primera ciudad del mundo cristiano en solicitar la definición dogmática de este Misterio resuelta por el Breve de Paulo V (1617), confirmado el 22 de mayo de 1622 . Este tema refleja perfectamente el ambiente

que lo trujiese se le quitara aunque sea el alcalde y los demás officiales dela cofradía, e que los hermanos que no pudieren yr descalços puedan llevar sus alpargates bastos sin ninguna pulidesa". Fol. 13v cap. XII: "[...] y a los lados los cofrades que fuesen señalados y nombrados con sus hachas y camisas negras, [...] con otros cofrades señalados con sus hachas vestidos de negro"

Al. SÁNCHEZ GORDILLO: Religiosas... Cit. p. 152: "van vestidos con sus tunicas de lienzo basto blanco, y la insignia de la cofradía pintada en un escudo de cordobán al lado izquierdo sin otras galas ni señal".

34. J.'SÁNCHEZ HERRERO: Los gremios, Sevilla 1980, pp. 24-25.

35. B.U.S. ms. 331/224, fols. 8 y $8 \mathrm{v}$.

36. A.H.P.S. Legajo 1224, fol. 713. C. LOPEZ MARTINEZ, Arquitectos..., cit. p. 62. Apen. Doc. 1

37. A. MARTÍNEZ RIPOLL: Francisco de Herrera..., Cit. pp. 140, 50-54.

38. A.H.P.S. Legajo 1224, fol. 713. B.U.S. ms. 331/224, fol. 7, Cap. 4: "[...] la qual dicha cera es nuestra voluntad que sea verde e no de otra color con un escudo de nuestra advocación y cofradía pintado en la dicha cera".

El mss. de Aldana está recogido por J. CARRERO RODRÍGUEZ en Anales de las cófradías sevillanas, Sevilla 1984, p. 638. Al. SÁNCHEZ GORDILLO, cit. p. 152:" [...] y las hachas con que se alumbran, de cera amarilla que es señal de dolor".

39. P. DE LUGONES, Carta..., Cit. nota 5 
religioso hispalense de la segunda década del siglo XVII y su iconografía fue gestándose hasta mediados de la misma centuria ${ }^{40}$.

El cuadro central está ocupado por la Virgen con las manos plegadas hacia la izquierda, planeando en un cielo aurífero sobre el cuarto creciente de la Luna; numerosas cabezas de angelitos cierran los ángulos de la composición. La disposición de la Luna y la indumentaria de la imagen -manto azul y túnica jacinto- no siguen los postulados de Pacheco, al igual que otras muchas de este período. El movimiento de los paños y su ampulosidad rompe un poco los planteamientos tardomanieristas. Esta concepción volumétrica puede ser una influencia de su hermano, que así pintó en 1616 la denominada Inmaculada de los Gorreros para las Gradas de la catedral hispalense, identificada por Valdivieso. La composición de los paños recuerda más a la Inmaculada del Museo de Estocolmo (h. 1635-1640) y a la del dibujo de la Academia de San Femando de fecha desconocida ${ }^{41}$. Los atributos que acompañan a la Tota Pulchra están situados en la orla, dentro de medallones inscritos en tarjas y dispuestos sobre paisajes idealizados, aunque el fondo arquitectónico del "Espejo sin mancha" y del "Pozo de aguas vivas" no dejan de evocar la Giralda sevillana, que simbolizaría la "Ciudad de Dios" (Lám. 3).

En conexión con la representación de la Inmaculada está otra plana con el prinsipio de la regla donde se representa en una inicial la natividad de la Virgen, rodeada por una orla vegetal, que ocupa casi dos terceras partes de la caja destinada al texto y corresponde a la invocación ${ }^{42}$. La escena del nacimiento de María, concebida sin pecado original, se acopla perfectamente a la $E$ que compartimenta la alcoba donde una Santa Ana, bastante joven, es atendida en el lecho por dos mujeres que le llevan los primeros alimentos; en la parte baja las mujeres acaban de bañar a la Niña y comienzan a vestirla. La disposición de la escena puede recordar, con licencias, alguna de las dos estampas de Cornelius Cort que describe Francisco Pacheco y tanto influjo ejercieron (Lám. 5).

Las orlas que rodean estos folios ofrecen un constante empleo de roleos, figuras aladas, motivos de origen floral y tarjas manieristas, que centran elementos iconográficos vinculados a la representación central. La disposición de elementos florales formando roleos tiene un tratamiento más barroco a las que pueden verse en la ejecutoria de Arias Pardo de Cela, realizada por el pintor-iluminador sevillano Diego Gómez hacia $1601^{43}$.

40. J. FERNÁNDEZ LÓPEZ: Programas iconográficos de la pintura barroca sevillana del siglo XVII, Sevilla 1991, pp. 90-96.

41. A. MARTÍNEZ RIPOLL: Francisco de Herrera, cit. pp. 55-56, cat. P. 93, p. 92, y D. 18. E. VALDIVIESO, "La pintura en la catedral de Sevilla, siglos XVII al XX" en La catedral de Sevilla, Sevilla 1984, p. 415-416, lam. 395.

42. Fol. 3. La inicial ocupa doce renglones de alto; $109 \times 91 \mathrm{~mm}$.. A.S.H.P. Legajo 1224, fol. 713. C. LOPEZ MARTINEZ, Arquitectos..., cit. p. 62. Apén. Doc. 1

43. La disposicón de estas orlas queda establecida por el contrato vid. notas 32 y 24. Museo Lázaro Galdeano, ms. 447. J. HIDALGO OGAYAR: "Diego Gómez, pintor-iluminador del siglo XVII" en Velázquez y el arte su tiempo. V Jornadas de Arte (Madrid 10-14 diciembre 1990), Madrid 1991, pp. 239-246. Fig. 1 y 3. 


\subsection{Letras capitulares}

En la decoración de manuscritos las letras capitulares realzan la importancia del texto a tenor de una cuidada jerarquización formal y decorativa, prevista por el copista y realizada por el iluminador. Los distintos tamaños y sus formas anuncian visualmente al lector el ritmo e importancia del texto. Esta organización es siempre gradual y en estas reglas se distinguen tres grupos.

El primero son las iniciales con figuras que comienzan las partes textuales de los capítulos I-LII y son las únicas contempladas en el contrato: todas las letras de los capitulos con figuras de santos ${ }^{44}$. Éstas se acoplan al vástago vertical de la letra sobre un fondo dorado, son cuadradas y ocupan siete renglones de alto aunque en ocasiones debido a su inserción en la caja escrita decrecen de tamaño ${ }^{45}$. Los trazos horizontales en las $I$ de los Item tienen una ancha moldura con horajasca superpuesta que termina en una voluta. Las iniciales $Q$ y $P$ de los capítulos I y II poseen las mismas características estilísticas que la mayúscula de la invocación. Todas presen$\tan$ elementos ornamentales iguales a los que pueden verse en el Oficio de San Gabriel de la catedral de Sevilla, especialmente la capitular del fol. 1v, donde encontramos la misma cabeza de angelote. El diseño de la Anunciación de este coral tampoco es lejano a los modelos, y quizás la factura sea de Juan de Herrera ${ }^{46}$. Las figuras están siempre erguidas y en los rostros predomina el dibujo subyacente, pero en ocasiones los rasgos son mas difuminados, quizás porque Juan de Herrera tuviera alguna colaboración en el taller ${ }^{47}$.

El ornato decorativo de estas mayúsculas se mantiene en la segunda jerarquía de iniciales en los folios $43 \mathrm{v}, 45 \mathrm{v}$ y 46 . Tienen el mismo tamaño que las anteriores, carecen de figuras y destacan otro contenido textual y cronológico. Las dos primeras corresponden a la Bula enviada por el Dr. Ortiz de la Vera Cruz de Toledo y se disponen sobre un fondo dorado; la tercera es el capítulo LIII, copiado después de 1634 , que presenta un fondo carmín ornamentado con trazos dorados. Este tipo de capital y su decoración fue bastante empleado por los iluminadores sevillanos, como

44. A.H.P.S. Legajo 1224, fol. 713. C. LOPEZ MARTINEZ, Arquitectos..., cit. p. 62. Apén. Doc. 1 45. Siete renglones $63 \times 63 \mathrm{~mm}$.; seis renglones en fols. $36 \mathrm{v}$ y 39 de $54 \times 54 \mathrm{~mm}$; cuatro en fol. 33 , mide $36 \times 36 \mathrm{~mm}$.

46. CATEDRAL DE SEVILLA, Librería Coral L. 25 , en los fols. 49 y 74 consta el año 1630 dentro de una inicial de tinta. La inicial del fol. 77 tiene una figura alada semejante a la tarja del fol. $2 v$ de la Regla de la Vera Cruz. T. LAGUNA PAUL, "Oficio y misa de San Gabriel arcangel", en Sevilla en el siglo XVII, Sevilla 1983, Cat. M.2, p. 271.

A.C.S. Libramientos del cabildo, Sig. prov. Leg. 0823 fol. 279v: "En 26 de abril 18.000 maravedíes a Sebastián Viçente Villegas, maestro de ceremonias desta santa iglesia, por tantos que el cabildo por auto capitular deste día le mandó dar ayuda de esta por una vez en consideraçion del travajo y ocupacion y gastos que tuvo en la composission y enquadernacion del Officio de San Gabriel y de 22 misas de santos de Sevilla que ha entregado en la libreria desta santa iglesia".

47. Por ejemplo: Juan evangelista, Bartolomé, Esteban, Cecilia. 
se ve en el fol. 21v de la Regla de la Antigua Hermandad de Alarifes de San Andrés, fechado hacia $1637^{48}$ (Lám. 8).

Las iniciales secundarias son mayúsculas de tradición romana realizadas en oro sobre fondo de color y dispuestas a tenor de una jerarquía textual diferenciando los títulos de capítulos del índice. Las primeras tienen cuatro renglones de altura (36 x $36 \mathrm{~mm}$.) y el fondo realzado con una decoración aurífera cuyos motivos recuerdan a las capitulares de los libros impresos contemporáneos. Las segundas presentan el fondo liso y dos renglones de alto $(18 \times 18 \mathrm{~mm}$.). La única inicial con hojarasca dorada es la del capítulo LIII, introducido después de 1634, y su forma recuerda a las que aparecen, entre otras, en la Regla de la Archicofradía de Jesús Nazareno de Sevilla realizadas en 1642 (Lám. 8).

Finalmente el primer renglón de todos los "incipit", salvo en la invocación que son cuatro, hay mayúsculas de tradición romana en oro sobre fondo de color labrado o no según corresponda a texto o título de capítulo, y las del mencionado cap. LIII presentan una inclinación hacia la derecha.

La ordenación iconográfica de las iniciales con figuras se ajusta al texto de las letanías, que era la plegaria colectiva cantada por la comunidad franciscana que acompañaba a los cofrades en la estación de penitencia ${ }^{49}$. Algunas veces las figuras aluden simbólicamente al contenido textual que destacan.

Siguiendo la letanía de los santos, en las tres primeras iniciales encontramos a San Miguel, San Gabriel y San Rafael (fols. 5-6v). En el folio 7 hay un cuerpo alado que podría corresponder a otra figura angélica en representación de todos los santos ángeles y arcángeles. No obstante su larga cabellera, el pecho señalado bajo la túnica jacinto y las manos enlazadas induce a pensar en una Inmaculada con alas, pese a carecer de Luna ${ }^{50}$ (Lám. 6).

Los capítulos V y VI tratan de las fiestas a celebrar por esta cofradía. La más importante es la de la Santa Cruz, tres de mayo, que tiene decorada la inicial con el emblema de la institución dentro de otra tarja (fol. 7v) (Lám. 6); el calendario anual tiene a San Juan Bautista (fol. 8).

Después del protoapóstol, desde el capítulo VII al XX hay un apostolado completo que incluye a San Pablo y San Bernabé, que no sigue estrictamente el mencionado texto. Los cinco primeros -Pedro, Pablo, Andrés, Santiago el Mayor, Juan (fols. $9 \mathrm{v}-12 \mathrm{v}$ )- siguen la jerarquía de dignidad establecida en las letanías

\footnotetext{
48. ARCHIVO DE LA HDAD. DEL PRENDIMIENTO DE SEVILLA. El folio $21 \mathrm{v}$ de estas reglas corresponde a una ampliación del texto aprobado en 1637.

49. El canto de las letanías está recogido por fray Fco. de Aldana al describir la procesión del jueves santo de 1621; Vid. J. CARRERO RODRIGUEZ Anales... cit. p. 638. El rezo de las letanías era al parecer usual en las procesiones de penitentes y claustrales según M. RIGHETTI, Historia de la liturgia, Madrid 1955, T. I. pp. 239 y 374.

50. Representaría esquemáticamente la huida de la Mujer atacada por el dragón del Apocalipsis, de la que no hay muchas representaciones en la Edad Moderna. Véase M. TRENS: Iconografía de la Virgen en el arte español, Barcelona 1946, p. 63-64.
} 
de los santos y los folios 13-16 se ajustan a las del Credo -Felipe, Bartolomé, Tomás, Mateo y Santiago el menor- (Lám. 6). Finalmente para Simón, Judas Tadeo y Matías no existen diferencias en la colocación porque en el Credo, en el Canon de la misa y en las letanías tienen la misma disposición ${ }^{51}$. San Bernabé (fol. 19v) sólo está contemplado en las letanías y fue incluido porque el 11 de junio era el día que la cofradía realizaba la dotación anual de doncellas; aparece representado en algunos apostolados grabados y pintados. A continuación encontramos los evangelistas Lucas y Marcos (fol. 20 y 21).

Un grupo compuesto por seis iniciales con doctores y padres de la iglesia (fols. $21 \mathrm{v}$ 25) preceden a los diáconos y papas, aunque en las letanías romanas los primeros van detrás. Su disposición en los folios -Gregorio, Agustín, Bernardo de Claraval, Jerónimo, Tomás y Ambrosio- no corresponde, en principio, a ninguna norma litúrgica, pues lógicamente los padres deberían preceder a los doctores. El doctor melifuo no presenta unos atributos claros y no puede descartarse que Juan de Herrera hubiera representado a otro doctor ${ }^{52}$ (Lám. 7).

En las cuatro capitales siguientes el iluminador dispuso a Lorenzo, Clemente, Vicente y Esteban (fols. 25v-28). San Clemente es el único papa presente en este grupo porque el 23 de noviembre es una fiesta local, que conmemora la entrada triunfante de Fernando III en Sevilla. El diácono Lorenzo está al comienzo porque su fiesta era la primera que celebraba la antigua liturgia romana después de San Pedro y San Pablo.

La parentela de Cristo decora las iniciales de los capítulos XXXIII al XXXV. San José con el Niño es el único contemplado en la letanía y se ajusta perfectamente a las representaciones de este período (fol. 28v). San Joaquín lleva un libro en las manos y está caracterizado como un profeta del Antiguo Testamento (fol. 29). Finalmente Santa Ana, de edad avanzada y de pie, lleva por necesidades compositivas en brazos a la Virgen, que está aprendiendo a leer (fol. 30).

Las iniciales de San Francisco de Asís y San Pedro de Alcántara corresponden a las escogidas entre los santos fundadores y reformadores, que en estas reglas lógicamente sólo podían ser franciscanos. Su inserción en los capítulos XXXVI y XXXVII responde claramente a una jerarquía hagiográfica, pero no puede descartarse una relación con el texto ${ }^{53}$ (Lám. 7).

51. M. RIGHETTI, Historia..., cit. T. I pp. 236-239

52. Podría ser también San Buenaventura. El santo del fol. 23 es tonsurado e imberbe; viste hábito o alba blanca y capa azul, y lleva como atributos un báculo de obispo y un libro. San Bernardo defendió en sus sermones la virginidad de María y su imagen estaba en la "maquina" levantada con motivo de la mencionada fiesta a la Inmaculada de 1615 que describió; P. de LUGONES, Cit. p. 19v. Quizás lo representó Francisco de Herrera en el lienzo "Doctores y padres de la iglesia que escribieron sobre el misterio de la Purísima Concepción de Ntra. Sra" de la serie de la Vera Cruz; Conde de la VIN̄AZA, Adiciones al diccionario histórico de los mas ilustres profesores de las Bellas Artes en España de D. Agustín Ceán Bermúdez, Madrid 1889, T. I p. 266.

53. B.U.S. $331 / 224$, fol. $30 v$, Cap. XXXVI "que trata sobre que se entierren los pobres que falleciere en casa de algun hermano cofrade". Fol. 312, Cap. XXXVII "sobre el horden que sea de tener para ratificar lo que hizieren en Cabildos". 
Finalmente, desde el capítulo XXXVIII hasta el XLII, Juan de Herrera iluminó quince iniciales con figuras de santas, vírgenes, y mártires. Su selección pudo deberse a la importancia que había adquirido la dotación de doncellas en esta institución, puesto que la mayoría son santas intercesoras o vinculadas a la historia y devoción de la Santa Cruz.

La primera es Santa Inés, patrona de las novias, y le siguen Santa Bárbara y Santa Catalina (fols. 32-33). Las dos últimas suelen emparejarse frecuentemente en las series iconográficas porque protegen a los moribundos y simbolizan la vida activa y la vida contemplativa ${ }^{54}$. Después encontramos a Santa Lucía (fol. 33v) y Santa Cecilia que, con su órgano portátil, pone armonía al capítulo titulado "sobre hacer amistades entre los hermanos discordes" (fol. 34v). Santa Elena, con corona y manto imperial, sostiene la cruz y los clavos de Cristo, objetos de veneración especial en esta cofradía (fol. 35v) (Lám. 7). María Magdalena, vestida con amplísimos ropajes, lleva el vaso de perfumes, símbolo de la caridad que llevó al sepulcro, y la cruz de penitente (fol. 36).

Santa Apolonia (fol. 39) precede a dos santas que portan flores. La primera lleva entre sus manos un paño abierto con rosas (fol. 37); la otra ostenta en la cabeza una doble fila de perlas que representan una corona y sostiene un cesto con las mismas flores (fol. 38v). Ambas carecen de cualquier otro atributo y quizás sean Santa Casilda de Burgos, a quien se invoca contra las hemorragias uterinas y la esterilidad en el matrimonio, y Santa Dorotea, patrona de los recién casados y parturientas ${ }^{55}$ (Lám. 7). Continua Santa Ursula con su flecha y palma (fol. 39); la siguiente, que viste de seglar con corona llevando un libro abierto y cruz en sus manos, debe representar a Santa Brígida de Suecia con la cruz y el libro de las Revelaciones, que fundó la orden del S. Salvador cuyo escudo lleva las cinco llagas que también están presentes en el emblema de esta cofradía (fol. 40). En el fol. 41 la inicial muestra una santa mártir con un libro y la palma de martirio, atributos muy genéricos para una identificación $^{56}$. Las dos últimas son Santa Agueda, abogada del mal del pecho, y Santa Engracia, a quien se invoca contra el dolor de cabeza (fols. $41 \mathrm{v}$ y 42 ).

\section{PERSONALIDAD ARTÍSTICA DE JUAN DE HERRERA}

Juan de Herrera no es un artista integral como su hermano, quien diseñó decoraciones arquitectónicas, retablos y realizó pinturas, iluminaciones y grabados, pero debía tener cierto prestigio dentro de su especialidad en Sevilla. El estudio de

54. L. REAU, Iconographie de l'Art Chretien, París 1955-1959, T. III/1 pp. 169-177, 262-272

55. La del fol. 37v también puede ser Santa Margarita sin dragón o Santa Isabel de Hungría representada sin hábito de terciaria franciscana, como lo hizo Ferrer Bassa en el siglo XV. La del fol. 38 quizás Santa Isabel de Portugal.

56. Santa Eulalia de Barcelona lleva algunas veces el libro de las Actas de San Tirso. J. Fco. ROIG, Iconografia de los santos, Barcelona 1950, p. 101. 
la iluminación y el contrato permite establecer algunas hipótesis al respecto, teniendo siempre presente que estos artistas podían contratar a la baja, como en los grandes ciclos pictóricos.

Las noticias y pagos de iluminación en el siglo XVII, como en otras fechas, son escasas y la mayoría de las veces relativas a pintores que practicaban también esta especialidad. Francisco de Herrera, el viejo, iluminó dos ejecutorias de nobleza, por las cuales percibió 18,18 y 25 ducados respectivamente; ambas retribuciones no son muy diferentes si se leen detenidamente los contratos, pues las planas realizadas en 1618 se abonarían a 9,9 ducados y a 8,33 ducados la iluminada un año mas tarde ${ }^{57}$. No obstante estas cantidades son más modestas que los 80 ducados que Pacheco declara haber percibido por la ejecutoria de Pedro López de Verástegui, aunque también Herrera pudo contratarlas a la baja y no incluir en ellas materiales costosos, o simplemente corresponder esta diferencia a una autorevalorización del teórico sevillano ${ }^{58}$.

El contrato suscrito por Juan de Herrera sólo indica la cantidad total que percibiría, pero el análisis de la iluminación permite realizar una aproximación a los costes parciales al conocerse la tipificación tarifaria que tenían otros talleres de iluminación. Las características de las planas, iniciales figuradas, mayúsculas decoradas y letras de oro presentan no sólo diferencias de tamaño, sino de colores en su ejecución lo cual evidencia costes menores para el artista. Nuestro iluminador realizó en las dos reglas un total de ocho planas, incluyendo la invocación, que suponen aproximadamente una superficie miniada de $0,43 \mathrm{~m}^{2}$ en las páginas llenas y $\mathrm{O}, 20 \mathrm{~m}^{2}$ en las iniciales con figuras. La Regla de dotación de doncellas se ha perdido, desconocemos el carácter y numero de sus iniciales; por no mencionarse en el contrato hay que suponerlas decoradas como las de los folios $43 \mathrm{v}, 45 \mathrm{v}$ y 46 del manuscrito conservado. Calculando hipotéticamente que la Regla de doncellas tuviera 25 capítulos parece probable que las planas pudo cobrarlas Juan de Herrera entre 15 y 18 ducados; las iniciales figuradas, al ser 7,33 veces más pequeñas, a un precio entre 2,5 y 3 ducados cada una; lo cual arrojaría un resto aproximado de 30 ducados para las orlas, las iniciales decoradas y secundarias de las dos reglas.

Estos precios, que no dejan de ser un cálculo hipotético, situarían a Juan de Herrera como un profesional cualificado en la Sevilla contemporánea tal como denotan sus caracteres estilísticos. A tenor de esta Regla se presenta como un iluminador en plena madurez artística, con buena técnica, que toma sus modelos de pintores contemporáneos y maneja con soltura la inspiración tomada a partir de grabados, pero que carece de la personalidad arrolladora de su hermano.

Francisco de Herrera es su referencia más cercana a la hora de realizar sus obras. Se desconoce si practicó la pintura sobre lienzo, aunque sí hay constancia de su

57. La ejecutoria de Antonio Pérez, contratada el 3-1-1618, llevaba un escudo y una Inmaculada, y cobró 200 reales. En 1619 concertó con Pedro de Alvarado dos ejecutorias con tres planas por 50 ducados en total. Los extractos documentales están publicados por A. MARTíNEZ RIPOLL: Francisco de Herrera, cit. Apen. doc. Núm. 6, 8, y 16.

58. Fco. PACHECO, El arte de la pintura, opus cit. fol. 376v, T. II p. 37. 
labor en el diseño de grabados, como la portada del Novus index librorvm prohibitorvm et expvrgatorvum; editus auctoritate \& Iussu eminentissimi ad Reuerendendissimi D. Antonii Zapata, sacăda a buril por Alardo de Popma, impresa por Francisco de Lyra en 1632. En las reglas conservadas saca un extraordinario partido del grabado de la Orden Trinitaria y otros conjuntos fraternos como, por ejemplo, la serie de la Vera Cruz y la decoración de la iglesia del convento de San Buenaventura de Sevilla. En el frontispicio impreso se observa una evolución al reducir la ornamentación, pero la composición arquitectónica recuerda la misma influencia y la de retablos contemporáneos (Lám. 9).

Juan de Herrera conocía sin duda las estampas italianas y flamencas que inspiraban algunas composiciones de su hermano, incluso su propio padre las pudo tener por su condición de grabador. Martínez Ripoll ya apuntó la posibilidad de que las yeserías del sevillano convento de San Buenaventura estuvieran inspiradas en la obra de Fray Francisco Gonzaga De origine seraphicae religionis (Roma 1587) ${ }^{59}$. Este libro, que se encontraba en la biblioteca del Convento de San Francisco de Sevilla, comprende 104 grabados de los cuales una cuarta parte están atribuidos a Agostino Carracci y su escuela ${ }^{60}$. No obstante a Juan de Herrera le resultaba más cercano y cómodo de copiar la interpretación fraterna de estos grabados.

La misma influencia boloñesa puede verse también en otros artistas como el pintoriluminador Diego Gómez que se inspiró en la orla bélica del retrato de Giovanni Tommaso Costanzo (h. 1582-1585) para la cenefa que decora uno de los folios de la ejecutoria de Arias Pardo de Cela ${ }^{61}$. El empleo de estos modelos, junto a las figuras aladas y racimos florales pueden encontrarse también en estampas grabadas por Francisco Brizio y Tempesta, entre otros, e indican claramente como los iluminadores sevillanos del siglo XVII empleaban las mismas fuentes visuales que los pintores, pues muchos practicaban las dos técnicas. Unos motivos omnipresentes también en relieves, retablos y arquitecturas barrocas hasta mediados del siglo XVII, que reflejan el gusto de una época.

59. A. MARTÍNEZ RIPOLL, Francisco de Herrera, Cit. p. 86.

60. K. WAGNER: "Los autores franciscanos de la desaparecida biblioteca del convento de San Francisco", Archivo Hispalense 192 (1980) p. 217, $\mathrm{n}^{\circ} 285$. Sobre estos grabados vid: M" J. del CASTILLO "Temas iconográficos de las fundaciones franciscanas en América y Filipinas en el s. XVI", Archivo Hispalense XXXVIII (1981) 599-646; Al. NOVA "Postille al Giovane Cerano. La data di nascita, un comitente e alcune incisione inedite di Agostino Carracci", Paragone 397 (1983) 46-64; D. de GRAZIA: La stampe dei Carracci con i disegni, le incisioni, le copie e $i$ dipinti connessi. Catalogo critico, Bolonia 1984, pp. 135-142, lams. 156-158.

61. D. de GRAZIA, La stampe..., Cit. cat. nº 96, Lám. 123. Museo Lázaro Galdeano, ms. 447; J. HIDALGO OGAYAR, "Diego Gómez", Cit. lám. 4. 


\section{APÉNDICE DOCUMENTAL 1}

1627,22 octubre. Sevilla

Carta de obligación y concierto otorgada por Juan de Herrera, maestro iluminador, a favor de Lorenzo del Río estrada mayordomo de la Hermandad de la Santísima Vera Cruz, de Sevilla, comprometiéndose a realizar la iluminación de dos reglas para dicha cofradia por 3.300 reales de vellón, según las muestras presentadas, en un plazo de ocho meses, y recibe a cuenta la cantidad de 500 reales de vellón.

A.- A.H.P.S. Legajo 1224. Protocolo notarial ante Baltasar de Valdés. Oficio II, libro $3^{\circ}$ del año 1627 , fols. $713 \mathrm{r}-714 \mathrm{v}$

EDIT. parcial.- Celestino LÓPEZ MARTÍNEZ: Arquitectos, escultores y pintores vecinos de Sevilla, Sevilla 1928, pág. 62

Sepan cuantos esta carta vieren / como yo Juan de Herrera, maestro iluminador, / vecino de esta ciudad de Sevilla en la collación de San-/ta María, otorgo y conosco me soi conbenido y consertado y por esta presente carta me con-/bengo y consierto con Lorenço del Rio Estrada, / vecino de esta ziudad de Sevilla, mayordomo de la her-/mandad y cofradía de la Santísima Vera Cruz de / Nuestro Señor Jesuchristo, çita en el convento de San / Francisco de esta ciudad, a yluminar una regla / de la dicha cofradía y me obligo de la yluminar / y haser en ella las cossas siguientes:

- Primeramente una tarja en el principio de la / dicha regla.

- Y a la vuelta de la dicha tarja un Santo Christo con dos pe-/nitentes a el pie y su çenefa rebestida con figuras.

- Una plana de la ymagen de Nuestra Sennora de la Pura / y Linpia Consepsión.

- A la vuelta una tarja con la cruz y quatro donse-/llas con escapularios berdes y belas.

- Otra plana con el prinsipio de la regla.

- Todas las letras de los capítulos con figuras de / santos

- Las ordas de todas las planas an de ser labradas // (fol. 713v) de oro açul y carmín.

- Una tarja al principio.

Otra regla de las donçellas

- Una plana con vn Christo con Nues-/tra Sennora y San Juan.

- A la otra plana con una ymagen de Nues-/tra Sennora y las donçellas con escapularios açules y sus belas.

La qual dicha regla y obra que en ella e de / hazer me obligo a que la daré fecha y acabada / en toda perfeçión conforme a las muestras que / tengo entregadas a el dicho Lorenço del Río / Extrada sin exseder dello en cosa alguna /. La qual dicha regla me obligo de la entre-/gar como está declarado de oy día de la fecha desta carta en ocho meses cunplidos prime/ros siguientes, por rasón de lo qual a de ser / obligado el dicho Lorenço del Río Extrada de / me pagar o a quien mi caussa ubiere tresien-/tos ducados de a honse reales por ducado que balen / tres mill y tresientos reales. Por quenta de los qua-/les resibo del dicho Lorenço del Río Es-/trada quinientos 
reales en bellón y los tengo / en mi poder de que me doy por pagado y en-/tregado a mi boluntad; sobre en este renunçio la essecuçión / y leyes de la ynumerata pecunia y prueba de la paga, renunçio como en ellas se contienne; / y lo demás restante cumplimiento a los dichos // (fol. 714) tresientos ducados, que a de ser obligado de me / pagar o a quien mi caussa hubiere, luego / como le acabe de entregar luminada la dicha / regla en la fecha dicha >siendo a el dicho plaso de ocho meses<, y por ello le tengo de / poder contar con solo mi juramento de quien mi cau-/ssa ubiere, sin otra prueba de que quedo re-/lebado, si a el dicho plazo de ocho meses y como dicho es no le entregare la dicha regla lumina-/da en conformidad de las dichas muestras / y a su contento y satisfasión, contento e por / bien que el dicho Lorenzo del Río Estrada o quien / caussa de la dicha cofradía ubiere se pueda / consertar y consierte con otras personas o no / que le paresiere que me lo hagan en el presio y según / como con ellos se consertare y por lo que mas / le costare; y por los dichos quinientos rreales que / como dicho es tengo resevidos y por todas / las costas, dannos y intereses o menoscabos que / sobre ello se le siguieren y rescresieren me pue-/dan executar con solo su juramento de quien/ su caussa de la dicha cofradía ubiere, sin que / sea nesesario otro recavdo ni prueba aunque / de derecho se requiera de que le relebo yo. / Y a de poder ussar la dicha cofradía o quien / su caussa ubiere deste remedio y bía e executoria / apremiarme por todo rigor de derecho / e prisión a que le entregue la dicha regla fecha y aca/bada a su contento y satisfasión, y ussar de / lo vno o de lo otro o de anbos recaudos jun-/tos a la par y de cada vno no de por sí sin que / en nada le pare perjuisio. / Yo el dicho Lorenço del Rio Extrada por mi persona // (fol. 714v) y bienes me obligo a que entregándome la dicha/regla a el dicho plazo de ocho meses fecha / y acabada en conformidad de las dichas mues-/tras y a contento y satisfasión de la dicha / cofradía pagaré a el dicho Juan de Herrera o a quien / su caussa ubiere el dicho resto o cunplimiento a los di-/chos tresientos ducados a quien sentencia sin pleyto alguno; / y por ello y las costas me pueda executar con solo / su juramento o de quien su caussa hubiere sin otra / prueba de que le relebo, para el cunplimiento e paga / de lo qual damos poder a las justisias ante quien / esta carta paresiere para en por bía executoria y en otra mane-/ra y como por passada en cossa jusgada executen, la premien / y a cada uno de nos y nuestros bienes a la paga y cunplimiento de / lo que dicho es. Y renunçio las leyes y derechos de nuestro fabor y la qual renunsiaçión / y obligadas nuestras personas y bienes abidos e por aber.

Fecha / la carta en Sevilla, de otorgamiento del dicho Juan de Herrera en veintidos días / del mes de otubre de mil y seissientos y veintesiete annos y lo firmó en / este registro y presentó por testigos de su conosimiento que juraron en forma de derecho / ser el contenido a Juan Sanches alguacil de los veinte o vecino de Sevilla [?] y a Francisco Benedito plate-/ro de esta ciudad de Sevilla y son testigos Sebastián Lópes y Juan de Loayssa escribanos de Sevilla./

Entre renglones "siendo a el dicho plaso de ocho meses", y "mi" no valga.

Baltasar de Valdes, escribano público (rúbrica). Juan Rodríguez de Loayssa, escribano público (rúbrica). Juan de Herrera (rúbrica). Sebastián Lopez, soy testigo (rúbrica).

Y de otorgamiento del dicho Lorenço del Río Estrada en veinte y nueve días / del dicho mes y anno dicho y lo firmó en este registro a el qual doy fe. Escritos testigos los dichos escribanos de sevilla.

Baltasar de Valdés, escribano público (rúbrica). Juan Rodríguez de Loayssa, escribano público (rúbrica). Lorenzo del Rio Estrada (rúbrica). Sebastián Lopez, testigo (rúbrica). 


\section{APÉNDICE DOCUMENTAL 2}

1636,19 noviembre. Sevilla

Juan de Herrera reconoce haber recibido de Jerónimo de Barreda, mayordomo de la Cofradía de la Santísima Vera Cruz de Sevilla, 700 reales de vellón, resto de los 3.300 mrs. que le correspondían por la iluminación de dos Reglas que realizó para dicha hermandad.

A.- A.H.P.S., legajo 14.544. Protocolo notarial ante Juan Rodríguez de Loayssa. Oficio XXI, libro $3^{\circ}$ del año 1636 , fol. 1.158 .

EDIT. parcial. Celestino LÓPEZ MARTÍNEZ: Desde Martínez Montañés hasta Pedro Roldán. Sevilla, 1932, pág. 186.

Sepan cuantos esta carta vieren como yo / Juan de Herrera, vecino desta ciudad de Sevilla en la collación de Santa María, otorgo y conosco que e resevido i reseví de Jerónimo de / Barreda mayordomo de la cofradía de la Santísima Vera Cruz / sita en el convento de San Francisco desta ciudad, por mano de Juan / Mendes de Trapa su reçeptor y cobrador, seteçientos reales / de vellón que son de resto y a cumplimiento a los tres mill y treçientos / reales que yo ube de aber por la yluminaçión de las dos / reglas que yluminé para la dicha cofradía, de que otorgué escriptura / ante Baltasar de Valdés escribano público que fue fue (sic) de Sevilla en veinte / y dos de otubre de mill y seisçientos y veinte y siete, por-/que los otros dos mill y seiscientos reales restantes los ten-/go cobrados antes de agora y assí se me restan debiendo los / dichos seteçientos reales, los quales me paga en birtud de libran-/ça firmada de Prudencio de la Rentería y tomada la raçón / por Juan Munnoz de Duennas alcalde y contador que son de la / dicha cofradía, su fecha oy en este día que entrego origi-/nal con esta carta de pago en cuya virtud e reçevido los / dichos seteçientos reales en contado, de que me doy por pagado. / Y renunçio a las leyes de la pecunia y entrego / como en ella se contiene, y de toda la dicha cantidad otorgo esta carta / de pago en bastante forma, y por mi parte çhancelo doy / por ninguna la dicha escriptura del suso mencionada para / que no balga ni haga fee como sino se hubiera obtorga-/do, y por libre della a los bienes y rentas de la dicha cofradía / para no le pedir en raçón della cossa alguna y consiento / que la raçón de esta carta de pago se areste y ponga el / rejistro de la dicha escriptura.

Fecha la carta en Sevilla en diez / y nueve días del mes de nobiembre de mill seissientos y treinta y seis annos. Y el otorgante que yo el escribano público doy fe que / que conosco lo firmó de su nonbre en este registro. Testigos Luis de Carrión y Sebastián de Balderrama somos testigos.

Juan Rodriguez de Loayssa, escribano público (rúbrica). Juan de Herrera (rúbrica). Carrión, soy testigo (rúbrica). Sebastián de Balderrama, soy testigo (rúbrica) 


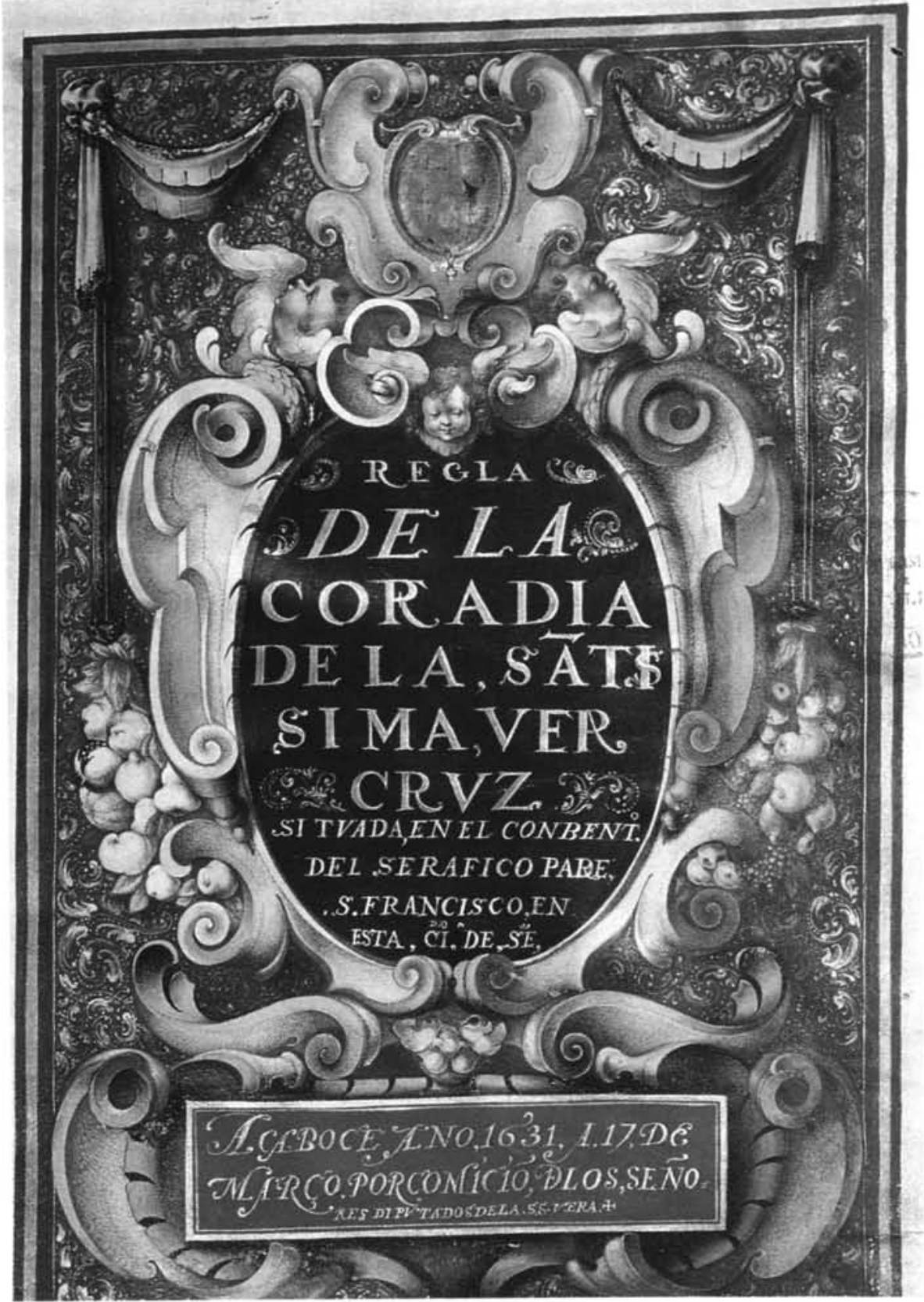

Lám. 1

Juan de Herrera. Regla de la cofradía de la Vera Cruz de Sevilla. B.U.S. 332/224, fol. 1. Frontispicio 


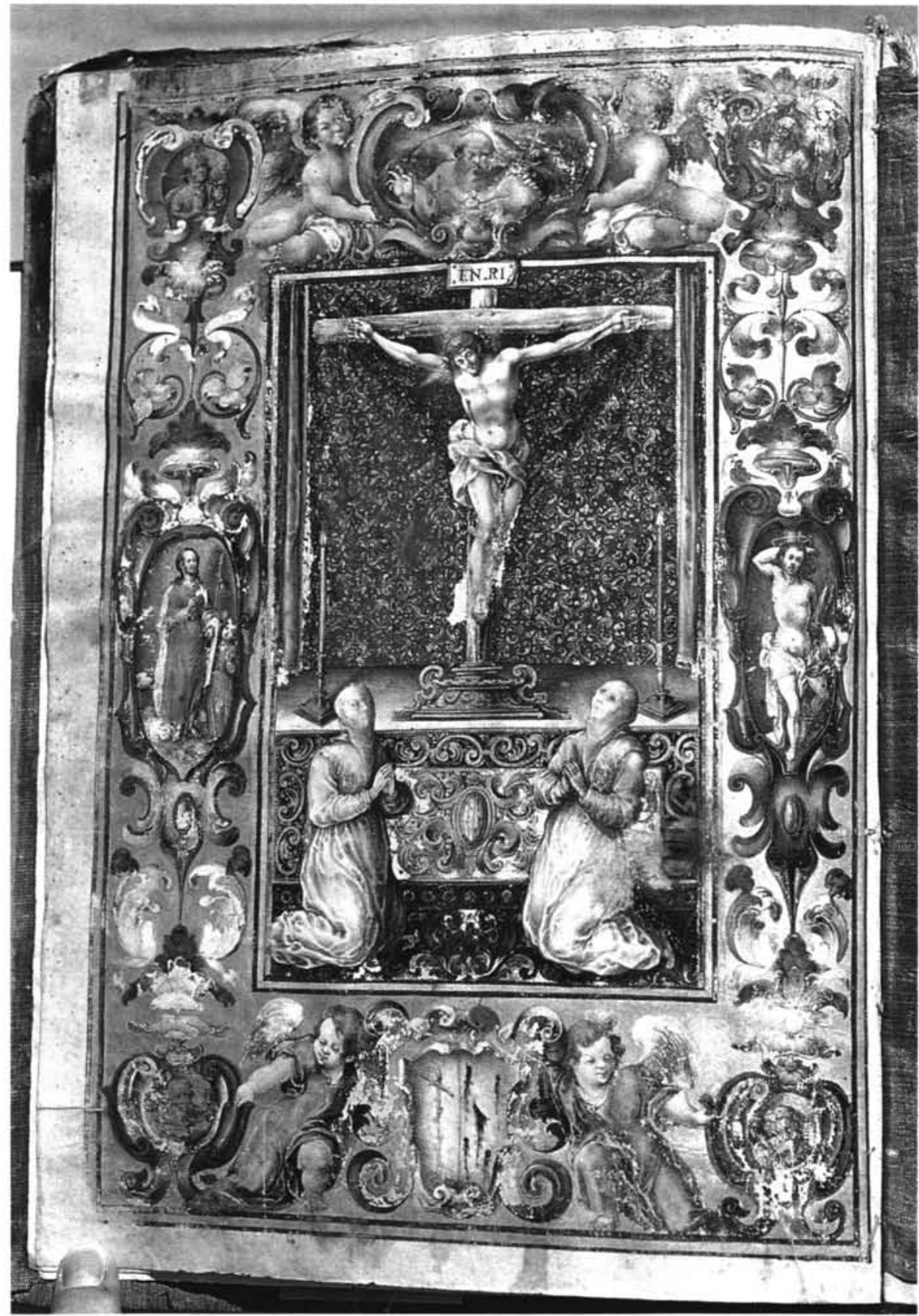

Lám. 2

Juan de Herrera. Regla de la cofradía de la Vera Cruz de Sevilla. B.U.S. 332/224, fol. 1v. Santo Cristo con penitentes de la cofradía. 


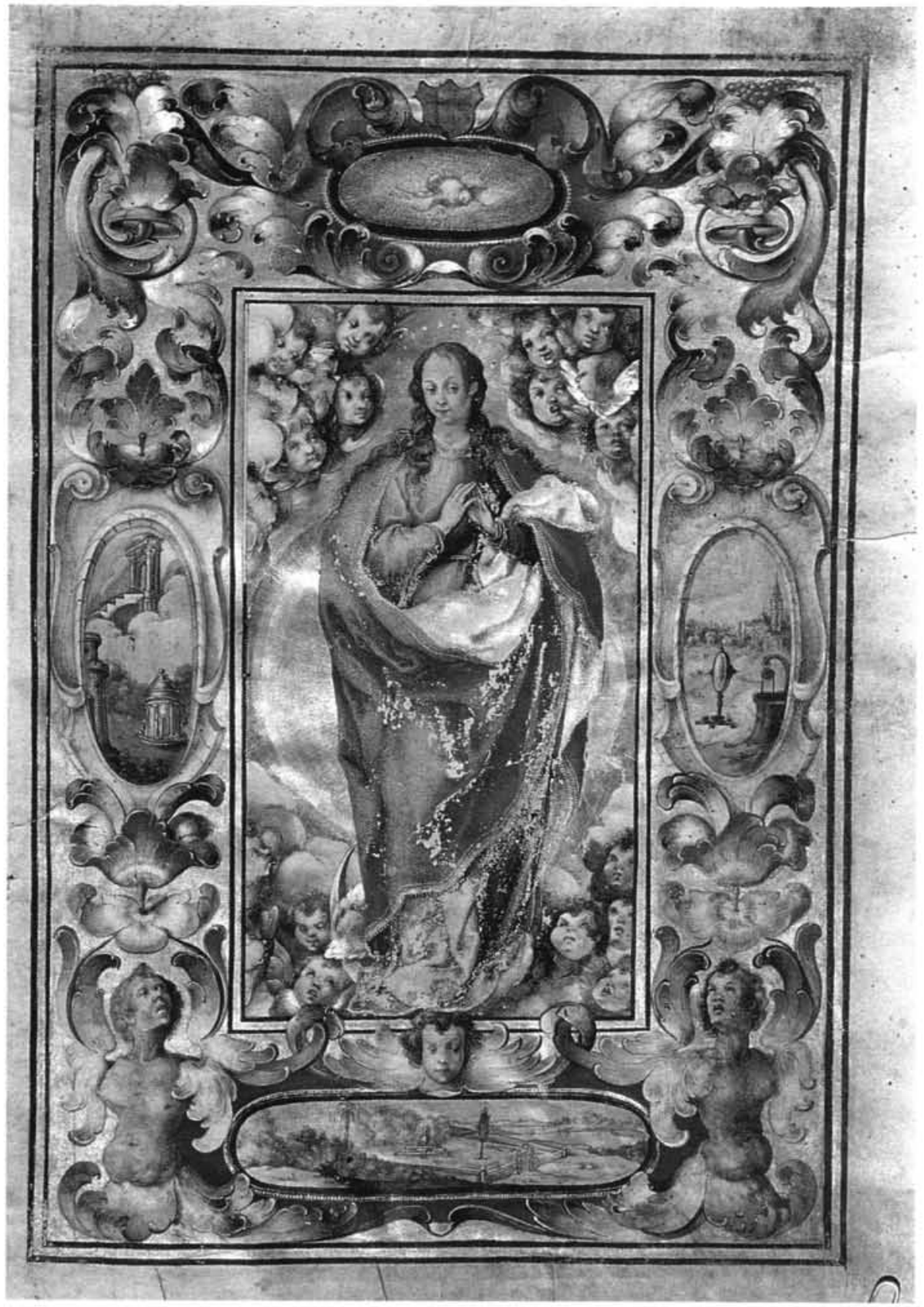

Lám. 3

Juan de Herrera. Regla de la cofradía de la Vera Cruz de Sevilla. B.U.S. 332/224, fol. 2. Inmaculada Concepción 


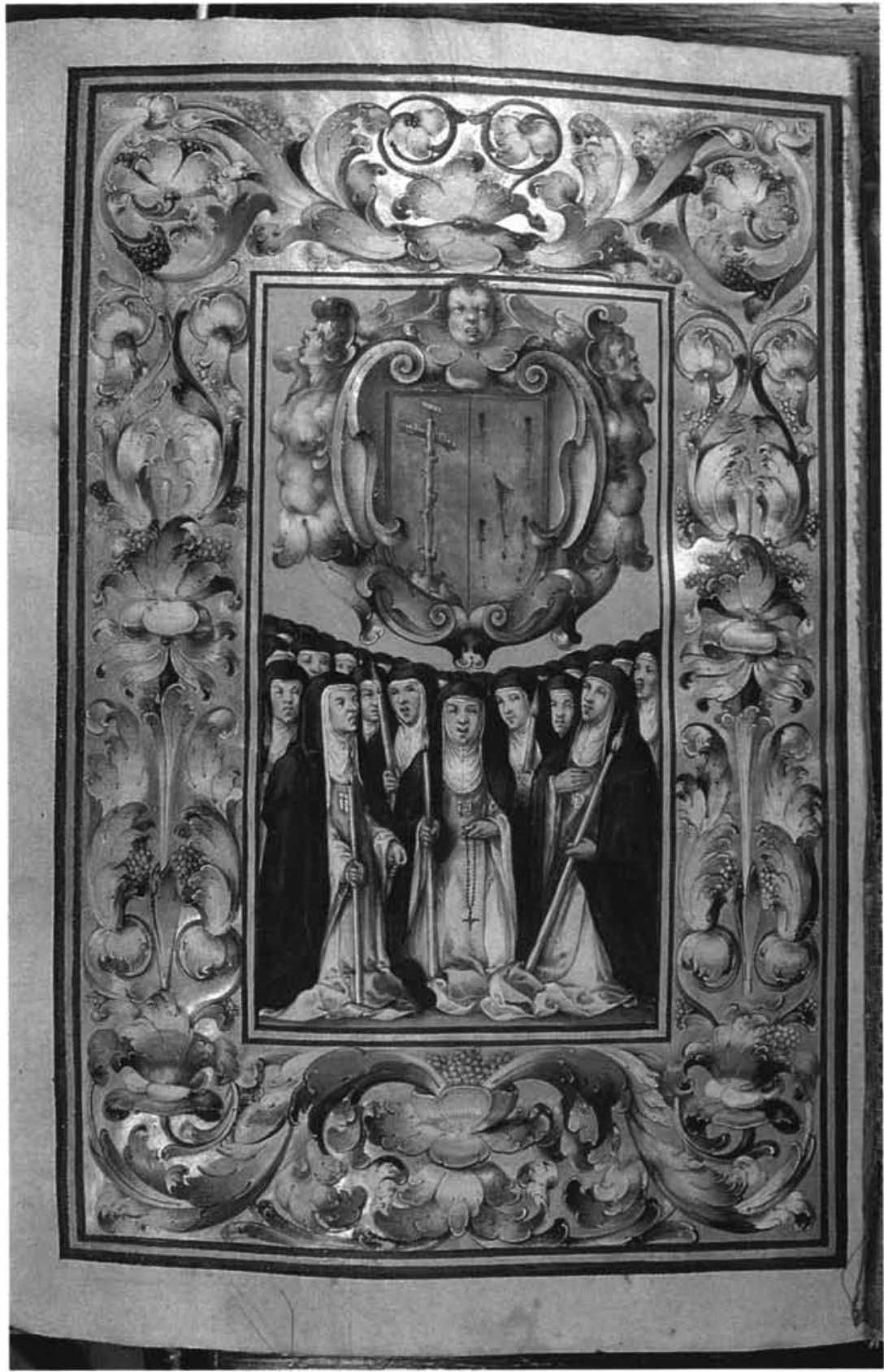

Lám. 4

Juan de Herrera. Regla de la cofradia de la Vera Cruz de Sevilla. B.U.S. 332/224, fol. 2v. Doncellas que dotaba la Hdad. de la Vera Cruz, bajo el escudo de esta cofradía. 


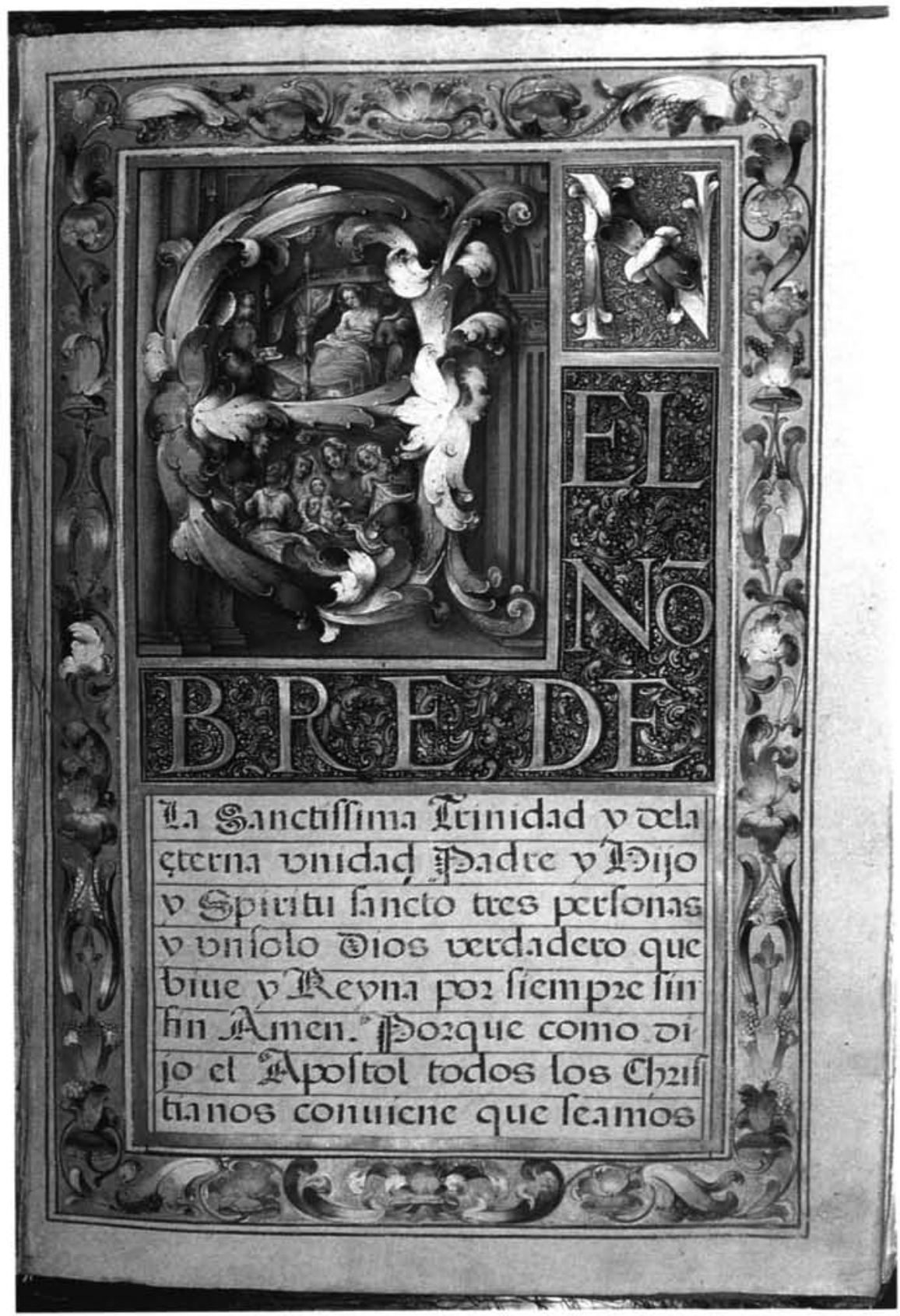

Lám. 5

Juan de Herrera. Regla de la cofradía de la Vera Cruz de Sevilla. B.U.S. 332/224, fol. 3. Nacimiento de la Virgen . 

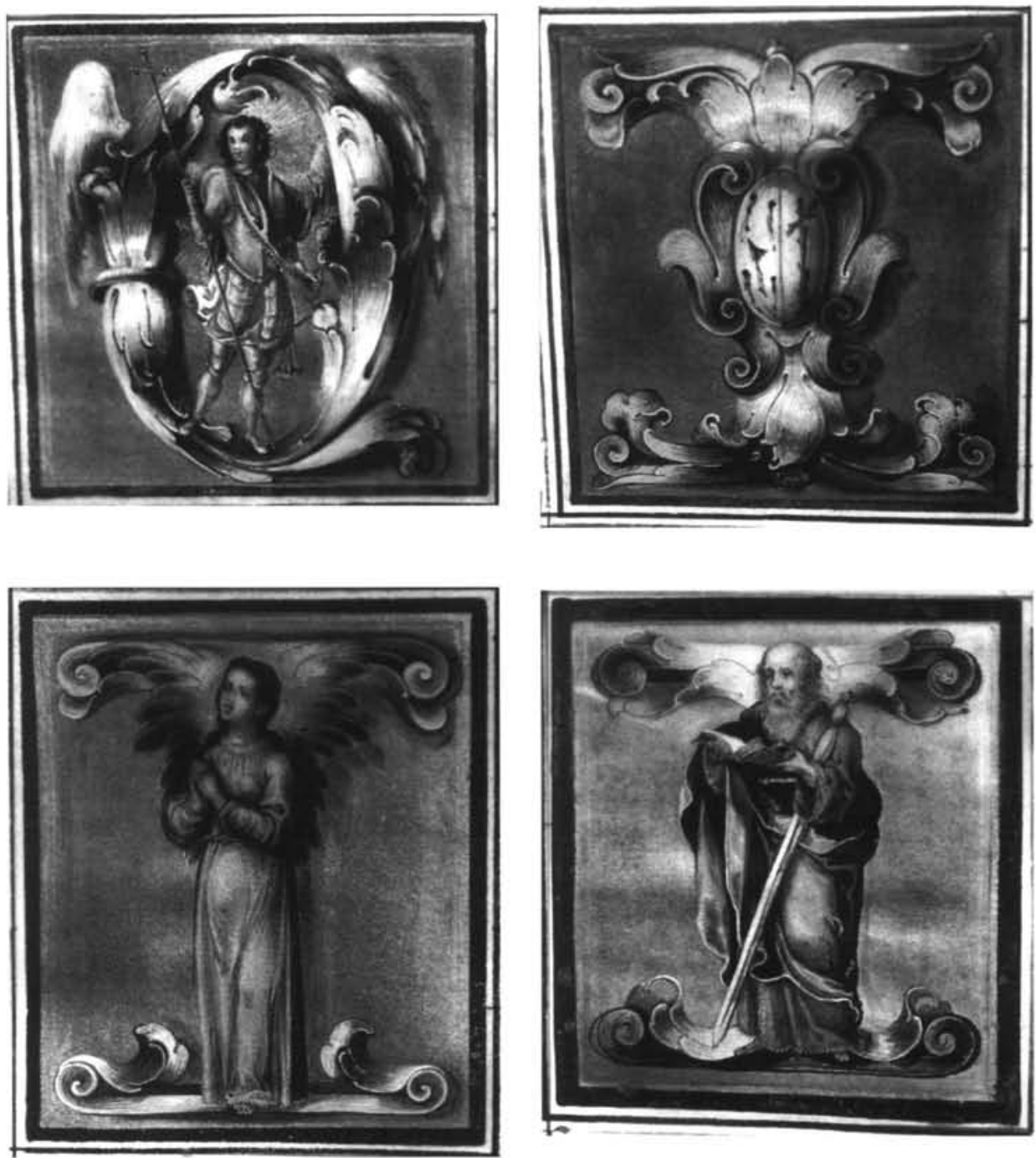

Lám. 6

Juan de Herrera. Regla de la cofradía de la Vera Cruz de Sevilla. B.U.S. 332/224, fols. 5, 7v, 7 y 10. San Miguel, escudo de la hermandad, Inmaculada, San Pablo 

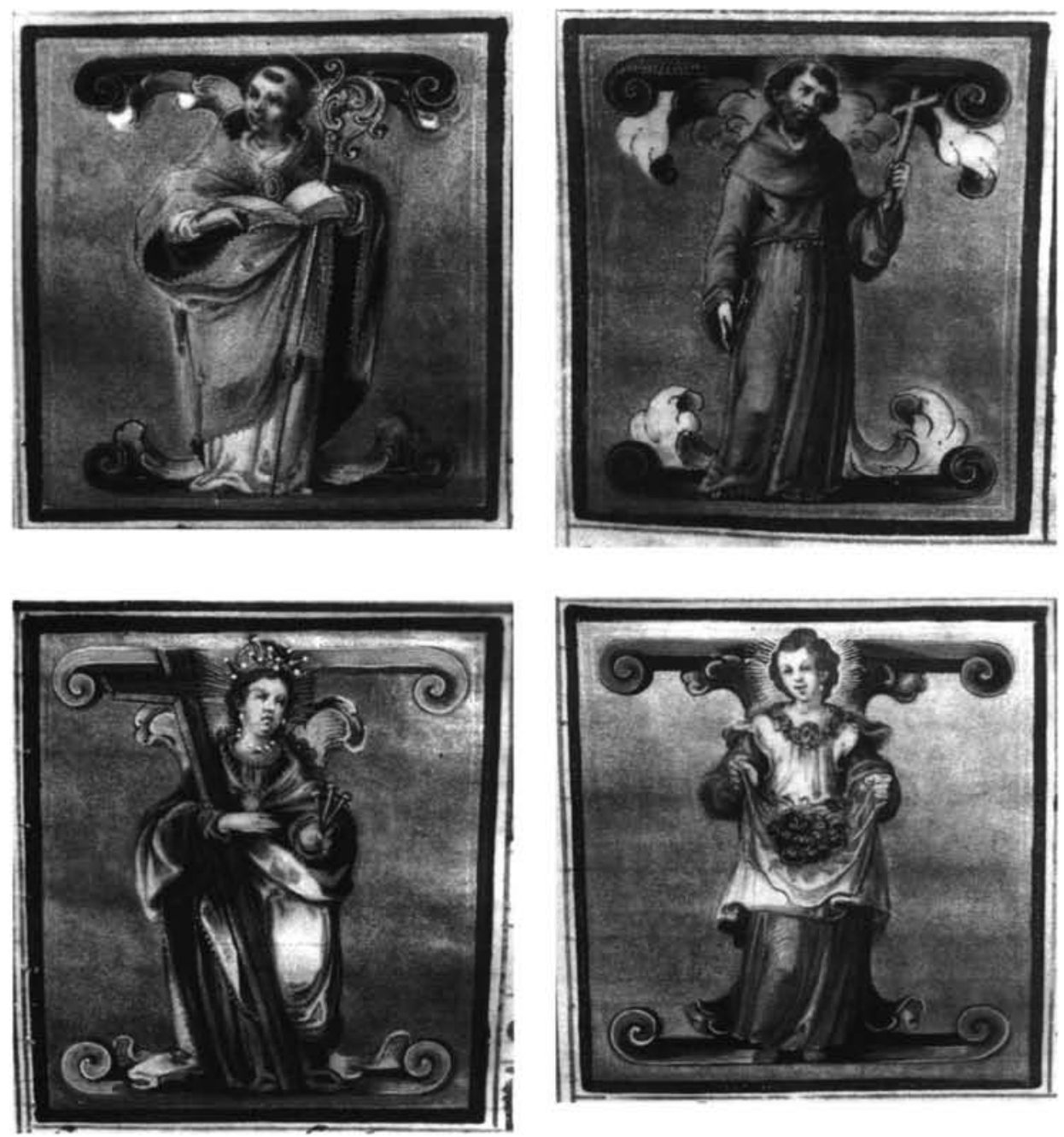

Lám. 7

Juan de Herrera. Regla de la cofradía de la Vera Cruz de Sevilla. B.U.S. $332 / 224$, fols. 23, 31, 35v y 37v. San Bernardo de Claraval, San Francisco, Santa Elena y Santa Casilda. 


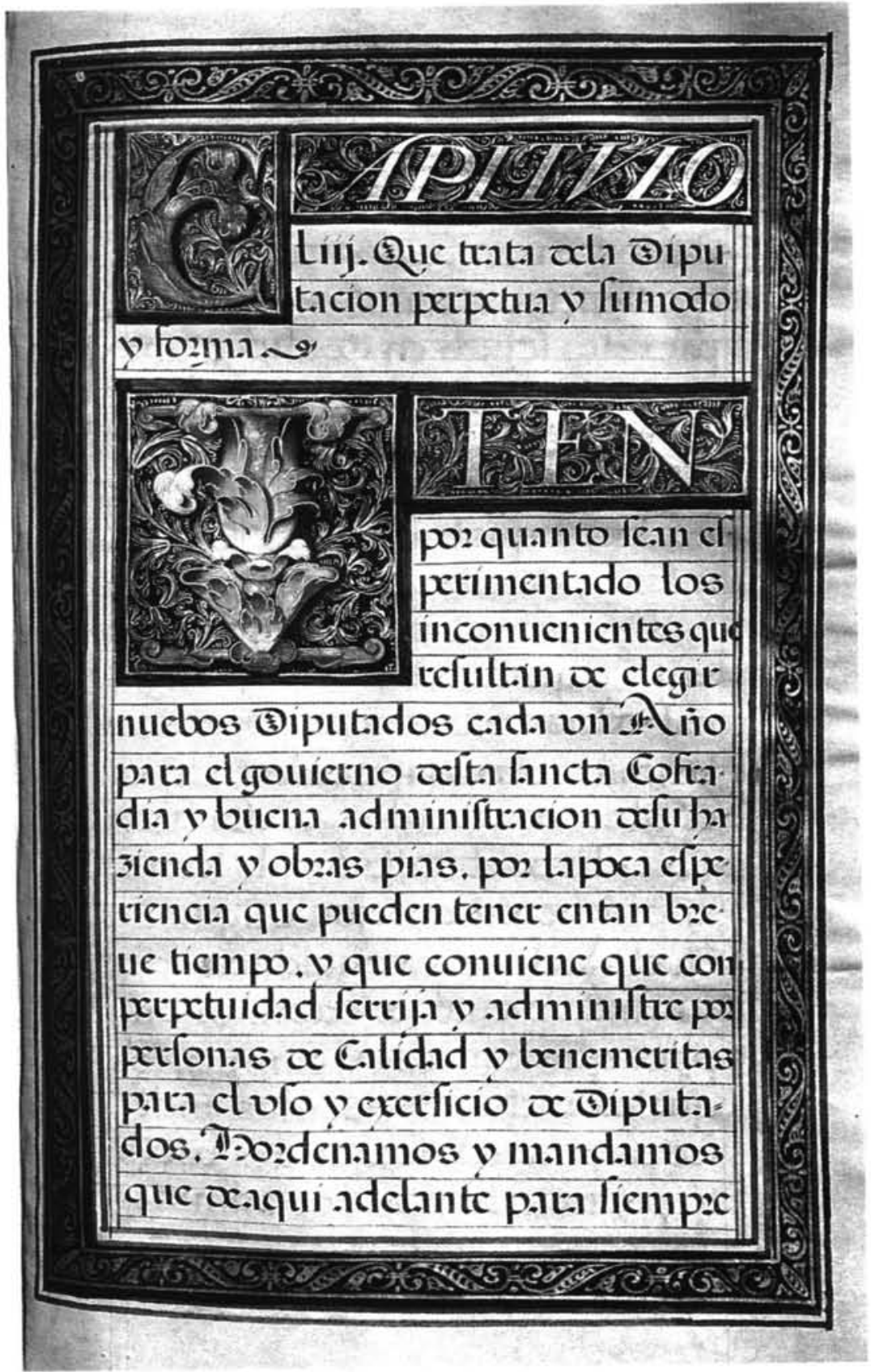

Lám. 8

Juan de Herrera. Regla de la cofradía de la Vera Cruz de Sevilla. B.U.S. 332/224, fol. 46. Capítulo 53, añadido después de 1634 . 


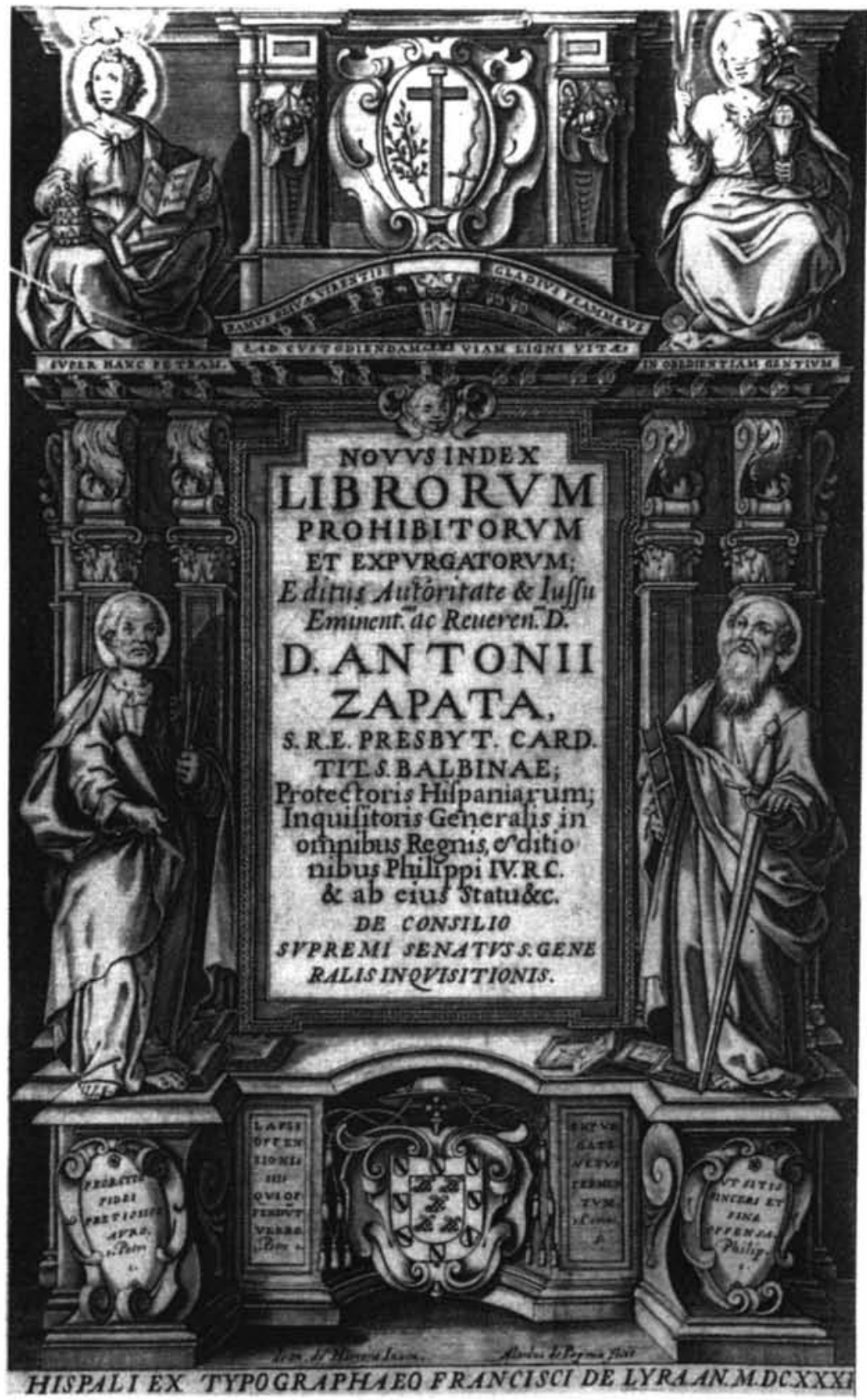

Lám. 9

Portada inventada por Juan de Herrera, grabador Alardo de Popma. Novus Index librorum prohibitorum et expurgatorum, Sevilla, Francisco de Lyra, 1632. 


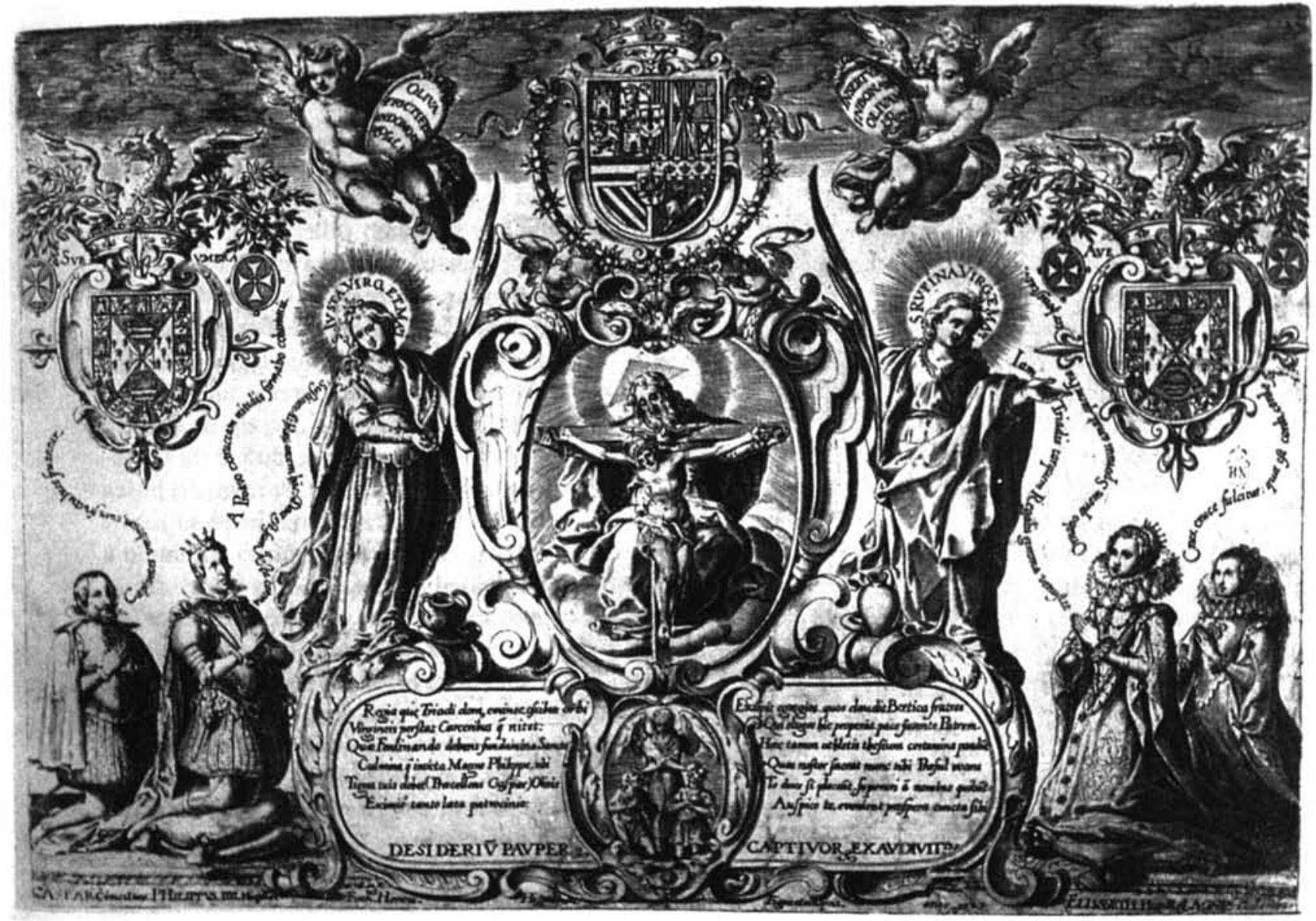

Lám. 10

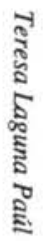

Francisco de Herrera, el viejo. Patronato o exaltación de la orden Trinitaria calzada de Andalucía, Sevilla 1627. (Biblioteca Nacional, Madrid). 